\title{
Wild Food, Prices, Diets and Development: Sustainability and Food Security in Urban Cameroon
}

\section{Lauren Q. Sneyd}

Geography and Collaborative International Development Studies, Department of Geography, University of Guelph, Guelph, Ontario, N1G 2W1, Canada; E-mail: 1sneyd@uoguelph.ca; Tel.: +1-519-824-4120 (ext. 53137); Fax: +1-519-837-2940

Received: 2 August 2013; in revised form: 15 October 2013 / Accepted: 25 October 2013 / Published: 7 November 2013

\begin{abstract}
This article analyses wild food consumption in urban areas of Cameroon. Building upon findings from Cameroon's Comprehensive Food Security and Vulnerability Analysis (CFSVA) this case study presents empirical data collected from 371 household and market surveys in Cameroonian cities. It employs the UN Special Rapporteur on the Right to Food's framework for understanding challenges related to the availability, accessibility, and adequacy of food. The survey data suggest that many wild/traditional foods are physically available in Cameroonian cities most of the time, including fruits, vegetables, spices, and insects. Cameroonians spend considerable sums of their food budget on wild foods. However, low wages and the high cost of city living constrain the social and economic access most people have to these foods. The data also suggest that imports of non-traditional staple foods, such as low cost rice, have increasingly priced potentially more nutritious or safe traditional local foods out of markets after the 2008 food price crisis. As a result, diets are changing in Cameroon as the resource-constrained population continues to resort to the coping strategy of eating cheaper imported foods such as refined rice or to eating less frequently. Cameroon's nutrition transition continues to be driven by need and not necessarily by the preferences of Cameroonian consumers. The implications of this reality for sustainability are troubling.
\end{abstract}

Keywords: urban Africa; Cameroon; wild food; diet; food prices; coping strategies; nutrition transition; sustainability 


\section{Introduction}

To complement staples such as corn, wheat or rice, Cameroonians that live near forested areas typically collect wild plant roots and leaves, fruits and nuts from trees, and hunt wild animals, fish and insects [1,2]. Foods hunted and gathered from forests contribute to food security through providing people with calories, animal and plant proteins, and essential minerals and micronutrients - especially iron and iodine, and also vitamins $\mathrm{A}$, the $\mathrm{Bs}, \mathrm{C}, \mathrm{D}$ and $\mathrm{E}$. These are essential micronutrients that not only create a more secure and varied diet, but also help to combat the effects of "hidden" hunger or micronutrient deficiencies [3-5]. While the economic value of "hidden" harvests can vary, these foods make significant and consistent contributions to Cameroonian livelihoods [6-9]. Also "hidden" at present are the contributions wild edible species make to national food balances (import-export sheets): the principal guides used to inform policies on food aid, trade and the domestic and international declaration of food crises [10]. With the routine "underestimation of wild foods comes the danger of neglecting the provisioning ecosystems and supportive local knowledge systems that sustain these food chains" ([11], p. 2913). When policies in forested countries obscure or neglect the routine consumption of highly nutritious edible local plant and animal products gathered from surrounding environments, they perpetuate the "hidden" status of these foods [12-14].

Much of the food security literature describes wild food consumption as a coping mechanism or adaptive strategy for increased household security when times are bad [15-17]. This common narrative depicts the gathering and consumption of wild foods as a reliable option when social or economic access to food at the market has been compromised either by environmental or income shocks. This account of wild food seems more likely in rural areas where there is greater access to and reliance on the surrounding environment for gathering wild foods. Researchers have conducted numerous studies on wild food utilization in rural areas [18-20]. However, in urban Cameroon, wild foods make a significant contribution to diets and to dietary diversity. Cameroon's food system is not only comprised of domestic agricultural (cultivated) products (including cassava, maize and plantain) and imported foods (such as rice and wheat), but also hunted and gathered forest foods (such as green leafy vegetables, spices, fruits, insects and forest meats). The engagements of city dwellers with wild foods are worthy of serious scholarly and food security attention.

Subsequent to the global food crisis of 2008 these so-called hidden foods have increasingly become foods that are only accessible to the wealthy or to the masses on special occasions. Food price inflation in many cases pushed locally produced and available wild foods out of the reach of average citizens. Average consumers nonetheless consider it culturally appropriate and desirable to prepare and eat these foods on a more consistent basis. This is not surprising considering the extent to which these foods contribute to the routine cuisine ([13], p. 4) Since the crisis, average urban Cameroonians have had to turn away from local wild products they would prefer to eat out of necessity.

This shift is disturbing given the limited state of knowledge about food in urban Africa. Crush and Frayne state that "nowhere is there any systematic attempt to... understand the dimensions and determinants of urban food security" across the African continent ([21], p. 532). They and others have identified a dearth of research on urban food security in sub-Saharan Africa [21-23]. In this research deficient context, even less is known about the contributions wild foods continue to make to the food baskets of urban dwellers. 
To address calls for a more systematic analysis of urban food security in Africa this article is guided by a central research question: what are the contributions of wild food products to food security in urban centers of Cameroon in the aftermath of the global food crisis? To answer this question, the article draws upon the UN Special Rapporteur on the Right to Food's understanding that food security challenges require a multidimensional approach [24,25]. While the framework advanced by Olivier De Schutter is not uncontroversial, it provides a coherent entry point for the assessment of wild food contributions. This approach emphasizes the physical availability of wild foods; the social, economic and physical access people have to wild foods; and the nutrition, safety and cultural appropriateness or adequacy of these foods in Cameroonian cities. This exercise consequently employs De Schutter's analytical dimensions to further knowledge about a seriously under-studied food security challenge. It is a highly convenient approach vis-à-vis wild foods, despite the fact that it is still hotly contested [26].

De Schutter has emphasized the over-arching consideration of sustainability in his work on each dimension of food security, and this emphasis is especially germane to this study. While some wild foods are now cultivated in urban areas, their hunting or gathering can have positive or negative impacts on the sustainability of forests, leading to their degradation, or alternatively, to their sustainable management [27]. Moreover, in urban Cameroon, the availability, accessibility, and adequacy of food can be enabled and compromised in unusual ways. Take for example a health scare linked to frozen imported chicken in the mid-2000s. As chicken consumers fell ill, civil society advocacy groups launched campaigns to highlight the food safety issues involved in the freezing and thawing of this "new" source of relatively cheap protein [28]. Without a reliable cold storage chain, this attempt to make frozen chicken parts available and accessible for a good price in cities raised questions about the safety and adequacy of this "cheap" meat. De Schutter's approach enables the comprehensive treatment of similarly "unique" issues.

In light of the lack of research attention on urban Africa and on food security challenges in Central Africa, this article aims to contribute to nascent conversations on the linkages between wild foods and food security in cities in the Congo Basin. After the 2008 global food crisis the Comprehensive Food Security \& Vulnerability Analysis (CFSVA) tool was drafted by the World Food Programme (WFP) to identify and assess food security situations in countries where the WFP is active. The CFSVA process generates a document that describes the food security status of various segments of a population across various parts of a country or region [29]. This article draws on the findings from Cameroon's CFSVA baseline study supplemented with interview and survey data gathered during fieldwork in Cameroon from 2010-2012 for a case study assessment of wild food consumption in Southern Cameroon. Through working with De Schutter's dimensions and applying them to the analysis of interview and survey data, it is clear that urbanites in Cameroon continue to rely upon wild foods, or at least continue to hope to rely on wild foods. Many spend more than 25 percent of their food budgets on wild products.

The next section reviews in more detail the literature underpinning the article's focus on wild food and food security. In the third section the country context and research methods are described. Section four presents the results and provides preliminary answers to the central question outlined above. Section five concludes the paper with a summary of key findings. 


\section{Literature, Concepts and Themes}

\subsection{Getting Wild: The Continuum of Human-Plant Interaction}

Through a literature review, Carolan notes numerous "turns" in agro-food studies that he describes as being less about "a specific theoretical framework as it is around a general way of doing agro-food scholarship" ([30], p. 1). He engages with the notion of "wild" as being a part of the theoretical terrain of "wild" in food research and encourages researchers to "get wild" in the spirit of discovery ([30], p. 15). Thus, rather than engaging in doing things "that tame...the future of agro-food research appears to lie increasingly in multiplication and of creating more entanglements not less" ([30], p.2). He states "...humans...are, "co-journeying" with food and agriculture across multiple spatial scales and institutional settings" ([30], p.5). This journey is continually remaking agricultural and food relations through the engagement with the natural environment and human culture [31]. It is with this spirit that the article engages with the term "wild".

Wild is not a simple concept, it can "evoke a sense of individualism and a bourgeois ethic of freedom," and can imply something that needs to be tamed ([30], p. 5). Similarly, environmental historians and geographers have found that "wilderness is not necessarily a fixed and objective concept" ([32], p. 204). Rather it is one that is formed on the basis of individual perceptions, expectations and cultural values. The environments in which wilderness might be found have an "objective ecological reality, and usually one that largely excludes obvious human modification" [32,33]. What makes wilderness "wild" rests very much with the individual, and her or his emotions, values and experiences $[31,34,35]$. From this, a series of "wildernesses" can be identified. These "multiple perceptions of wilderness", that are peculiar to particular groups can be collected, organized and mapped ([32], p. 204). Just like there are many types of "wildernesses", there are many types of "wild". Thus wilderness and wild have both an ecological and a human perceptual meaning.

For paleoanthropologists, ethno-botanists, and ecologists, the accumulation of plant-based knowledge follows from repeated observation of the effects certain plants have on the formation of human culture $[13,36,37]$. The terms wild, cultivated, and domesticated actually represent points on a continuum of increasing interference with the natural ecosystem that defines the human-plant relationship. At one end of the continuum are the "entirely wild" which grow outside the man-disturbed habitat [38]. Thus the term wild often applies when a plant's habitat does not include secondary (human disturbed) habitats such as open areas, thickets, roadside, old fields, edges of fields etc. [39]. At the other end of the continuum is noticeable human intervention such as "selective harvesting, transplanting, and propagation by seed and graft" [13,39]. This explanatory framework has been around since the 1960s and "emphasizes the continuities between foragers" reliance on wild species for "food procurement" and agriculturalists' reliance on domesticated species for "food production" [13,38,40]. However, in tropical forest "even disturbed secondary rainforest might first appear to be pristine" $[41,42]$. Darrell Posey, for example, working with the Kayapo people of the Brazilian Amazon, has shown that certain "wild" plants along paths through "pristine" forest have been in fact planted by the Kayapo as a source of food, medicine and other resources. It was not until biologists began talking to local people, that they found they had been misled by their own definitions [43,44].

Foraging and farming across the world are "overlapping, interdependent, contemporaneous, coequal and complementary" [11,38]. Within these systems there are no easy distinctions between "wild" and 
"cultivated" foods. While food research and policy tends to consider these types separately, many local communities rarely make distinctions between foods from the forest or the field $[5,45,46]$.

This complexity is the result of particular local knowledge that is then "encoded into norms, rules, institutions and stories, and this forms the basis for continued adaptive management" of food systems and environments over generations [11,46-48]. The continued availability of these plant foods depends on the maintenance of synergies between farming practices and wild biodiversity [49,50]. In turn, food agro-biodiversity is inextricably connected with cultural heritage [45,51,52]. To focus on food and culture, as well as food and dishes always "reflect the regional identity of people, ethnic groups and communities, and the use of wild food plants is an example that exemplifies local knowledge or traditional ecological knowledge" [5,20,53]. Ethnographic and empirical findings from the survey show that in southern Cameroon, these specific foods simply "come from the forest" or "come from the bush". Cultivated foods "come from the fields." Viewed in this way, it is the forest that provides the "wild foods" and these include edibles that are not only plants [54].

The role and value of forests to food security is grossly underestimated [1,9,55]. Some research suggests that forest-dependent people who live in or near forests tend to be politically weak and hold very little power in decision-making processes relating to the management of forests ([55], p. 1388). This is reinforced by forest-dependent people's geographic distance from urban centers where political alliances that might favor forest conservation tend to be formed and maintained [56]. The Food and Agriculture Organization (FAO) estimates that globally, over one billion people continue to rely on wild foods to meet their food needs [57]. Pimental et al. has found that "healthy forest ecosystems are essential to world food security because they (i) directly provide food to large numbers of people; (ii) produce products and employment that enable people to purchase food; (iii) [and] protect the environment [in ways] that help...the productivity of forestry and agriculture" ([1], p. 111).

In research on Cameroon the distinctions are further complicated by the concept of non-timber forest product (NTFP) or non-wood forest products (NWFP). NTFPs are "all biological materials other than timber, which are extracted from forests for human use" ([58], p. 161). This literature has tended to emphasize this definition, however this definition includes non-edibles. When NTFPs are mentioned in the literature on Cameroon, the focus is often on quantifying yields sold in local markets [59-63] and measuring their economic importance through focusing on rural employment and income [64-67]. Making the distinction between all materials and edibles is important for an urban food security study as urbanites are purchasing these foods for home consumption in markets. The past and current research lacks a critical element of the NTFP trade in Cameroon: their use by urban residents, the ways they feature in urban diets, and their contributions to food security in urban areas.

The global food crisis has sparked renewed attention to wild or "hidden" foods for food security [68-70]. These foods are being recognized for their contributions to dietary diversity and nutritional security [69,71]. It is encouraging to highlight international interest and renewed attention on biodiversity and the sustainable use of these significant crops across Africa [68,72-74]. It is well known that these forest foods make invaluable contributions to households' food security [11,12,14,45,75-77]. For example, turning back to the CFSVA for Cameroon the report describes higher levels of food security in the forested region of the country than in the Sudano-Sahelian north [78]. While this can also be attributed to changing weather and unrest in neighboring countries that border northern Cameroon, forested foods in the south help to compliment agricultural products and imported food. Similarly, findings 
from a study of the nutrient composition of "bush meals" from Cameroon's northern regions stress the fundamental role of wild food for nutrition and their sustainable use for increased food security [79].

\subsection{Urbanization and the Availability, Accessibility and Adequacy of Wild Food}

Increased urbanization (as a result of rural to urban migration) across the African continent is an important factor that expands the size of local, urban wild food markets [21,80]. This movement and the ensuing food trade creates a new type of consumer who, unlike rural inhabitants, has to buy wild products rather than gather them [61]. Urban individuals (and households) are generally net food buyers who rely on their income for their food security, spend a large proportion of households' budgets on food, and have little access to other safety nets like agriculture or land to ensure food access in times of crisis $[21,81,82]$. Consequently, the buying and use of wild foods in this environment becomes more about food choices, personal preference and household budgets than the wild "famine foods" touted in the literature [68]. Globally, people purchasing food to meet their daily needs dominate the urban scene [21]. Poverty is no longer found only in rural areas but in urban areas as well. That being said, food insecurity is probably higher among the urban poor than among the rural poor and this was demonstrated during the food price crises in 2008 [15,16,25].

More specifically, Cameroon is considered a highly urbanized country by sub-Saharan standards. A recent 2010 estimate from the United Nations World Urbanization Prospects suggests that Cameroon's urban population is $58 \%$ of the total population [83]. Despite strategies aimed toward reducing rural poverty, urban poverty is somewhat ignored [21,81]. Further, economic growth in Cameroon is not on target and the country is not on target for meeting the Millennium Development Goals [84]. Urban poverty in Cameroon is best described as poor access to adequate infrastructure, a lack of social services and income poverty. In the literature on urban Africa, it is often explained that the high costs associated with "urban shelter, transport, health and education undermine the ability of the chronically poor to access sufficient food" ([21], p. 536). All things considered, Toye predicts that the economic impact on development will be "hardest for low-income urban households in developing countries that are net importers of food" ([85], p. 761). The literature on food in urban Africa highlights factors beyond actual production and availability of food by drawing attention to the social and economic access to food and the realities of balancing household budgets in a deteriorating urban environment [86].

The knock-on effects of the 2007/2008 food crisis "drew attention to the vulnerability of the world's poor, especially the urban poor" ([87], p. 350). The perception that food will always be available in cities was altered for many in 2008, when the food prices peaked and reached levels not seen since the 1970s [88]. The world's poor suffered the greatest blow as food prices rose to unattainable levels, rations decreased or disappeared, and frustrated people took to the streets in protest [89]. In particular, high global oil prices in 2008 sparked strikes and riots of taxi drivers in Douala and Yaoundé, Cameroon that halted the movement of food between cities [90]. Not only was food more expensive, it was more expensive to move it around the country. In these cities, the strikes are remembered as a time of low stocks in the markets and food shortages at home. The budget of low-income households is disproportionately skewed so that $50 \%-60 \%$ of household income is spent on food. However, the literature on food price shocks and volatile prices suggests that the food price crisis should not be seen as changes in people's income alone. Volatile food prices are a common feature of low to middle 
income economies where local markets are not regulated to protect the poor [91]. Food prices remained volatile over the subsequent years and remained above 2009 prices. For example, the CFSVA for Cameroon notes that food prices have remained higher than before the price crisis of 2008 [78]. Compared with the last five-year average, prices for "maize and cassava increased by $18 \%$, rice by $33 \%$ and plantain by 39\%" ([78], p. 7). Governmental measures adopted after the food price crisis and subsequent food riots in major urban areas, "managed to bring food inflation down to an estimated $1.2 \%$ in 2010 " ([78], p. 7). While these measures assist with accessing staple foods, prices for local vegetables and wild foods remained high. The literature on food crises features the intersections of the availability of food and accessibility of that food. While it is assumed that food will always be available in cities, the food riots made it clear that food will not always be accessible.

The food price spikes of 2007-2008 and 2010-2011 have had far reaching effects on urban residents generally and especially on food choices within households in urban areas. Evidence from Swan et al. suggest that vulnerability to high food prices is likely to be associated with the type of staple food consumed, the ability to substitute cheaper foods, trends in income and the degree to which households rely on the market for food [92]. When food prices increased in 2008, Swan et al. learned from the Central African Republic, that households adopted damaging coping strategies. People in their study were reported purchasing less expensive foods with limited nutritional value, eating less preferred foods and reducing the diversity of their diets. Their findings suggest that food price shocks increase the risk of micronutrient deficiencies ([92], p. 111). Many urban poor people have little room to maneuver as coping mechanisms decrease food security. When food prices rise, households can: buy less food; buy lower quality food; reduce portion sizes; reduce meal frequency and buy less variety of food. These coping strategies affect nutrition and health. Generally, these strategies involve a shift in diets from sorghum, millet, maize and root crops to rice and wheat which are often highly processed, imported, subsidized and available cheaply [22]. Cereals such as rice, wheat and maize are the basis of the urban diet and because they are internationally traded they can leave the urban poor even more exposed to global price fluctuations [93]. A dietary transition most often occurs in cities where these "cheap" foods are most accessible and where high food prices exclude the poor from accessing healthier food options or traditional foods. The term "nutrition transition" was coined to describe the process that happened many decades ago in developed countries but is now occurring in developing countries [94]. It marks a shift in diet from simple staples high in fiber to a greater intake of saturated fats, sugar and refined foods [95-97]. The transition accelerates the incidence of dietrelated non-communicable diseases [98].

As global food prices rise, this transition is more pronounced. In their 2007 study, Sharma et al. found that food composition data for Cameroon are severely limited [98]. Their study provided, "for the first time, the calculated nutritional composition of composite dishes commonly consumed in the urban and rural areas of the Central Province of Cameroon" ([98], p. 476). Their findings suggest that rural Cameroonians eat a more diverse diet and engage in more physical activity than their urban counterparts. The "rural diet is more or less based on the traditional staple foods, while the urban subjects incorporate more modern foods into their diet" ([98], p. 153) These include pasta and rice and beignets or deep fried balls of sweet dough made with wheat or cassava. The goal of these studies was to use these findings for "nutrition interventions aimed at modifying commonly consumed composite dishes to improve dietary intake" as nutritionists in Cameroon are noting alarming rates of obesity, 
diabetes and other diet related conditions [98-100]. Findings such as these are important because they demonstrate at the micro-scale of bodies the ways that the broader political economy impacts food choices, households' food security and ultimately public nutrition and health. The literature on coping strategies and nutrition transition relies on such dimensions as accessibility and adequacy. When the conditions are enabled that make food less accessible the adequacy of diets is compromised leaving households vulnerable to future dietary and health shocks [100]. What we can take from this body of literature is that "food security strategies of the urban poor, and how these are thwarted or enabled" are crucial for studies on urban food security ([21], p. 528). By using the three dimensions of food security outlined by De Schutter particular aspects of the literature stand out and drive this analysis forward. In light of neglected consideration of nutrient-rich foods in an urban environment and with this brief history and review in mind the methodology and results follow.

\section{Methodology}

Cameroon is an excellent territory for a case study of foods from the forest. Located in the equatorial and tropical regions of the Gulf Of Guinea, the South and East regions of Cameroon are located in the humid forest zone (HFZ) of the Congo Basin, and the Southwest region of Cameroon has been labeled a biodiversity hotspot $[101,102]$. However, some researchers have claimed that information on food provisioning systems in cities in Cameroon is "sparse and often too incidental for the purpose of advanced research", an analysis of this "system needs to be built from the local level" [103,104]. Therefore, this case study draws on empirical evidence the author collected during four separate research trips to Cameroon from July 2010 to December 2012. This study builds on the findings from Cameroon's CFSVA and the 2011 baseline survey of 6300 households from Cameroon's ten regions. From this CFSVA study, households responded to a questionnaire about their food intake, their sources of income, livelihoods and expenses, assets and various practices associated with strategies for survival [105]. The findings from urban areas suggest that urban dwellers experience a greater level of food security than their rural counterparts. However their situation is greatly impacted by rising food prices, as urban residents have to purchase the food they consume. The survey also argues that in the capital city and regional capitals food insecurity is almost non-existent [105]. Building on these findings, the present case study documents urban food security through focusing on wild food consumption in three cities in Cameroon: Buea, Limbe and Yaoundé to highlight the voices and experiences of the people in these cities. All three cities are located in the HFZ in Cameroon's Center and Southwest regions. These cities were chosen for in-depth qualitative research based on their locations within this zone where "foods from the forest" are primarily gathered and consumed. Etkin contends that diet surveys tend to ignore "wild plants" compared to dietary "staples". This is attributed to a "lack of understanding regarding which plants should be included in the "wild" category and the extent to which they contribute to routine cuisine"([13], pp. 4-5). But wherever the "consumption of wild foods has been accurately accessed, they emerge as regular and important elements of diet" [13,20,106-108]). When taken into consideration more nuance of the food security situation in these cities can be described and assessed through the inclusion of these "hidden" foods.

The research design focuses on the sellers and buyers of wild food products in urban areas. The maps below identify the markets and sites this study concentrates on in each location. Within each city, markets were randomly selected based on criteria such as size, location, days of operation and 
identification of wild food sellers. Geographic Information Systems (GIS) points were collected to map the locations of the markets in each city. The first map (Figure 1) charts the locations of eight markets and four restaurants in Yaoundé where wild foods are bought and sold. The second map (Figure 2) identifies nine markets around Buea and Limbe where wild foods are bought and sold. Subsequently, these sites and the circles on each map indicate the proximity of households to markets that sell forest foods. While these points are not exhaustive, they mark the sites this study concentrates on.

Figure 1. Map of households and markets, Yaoundé.

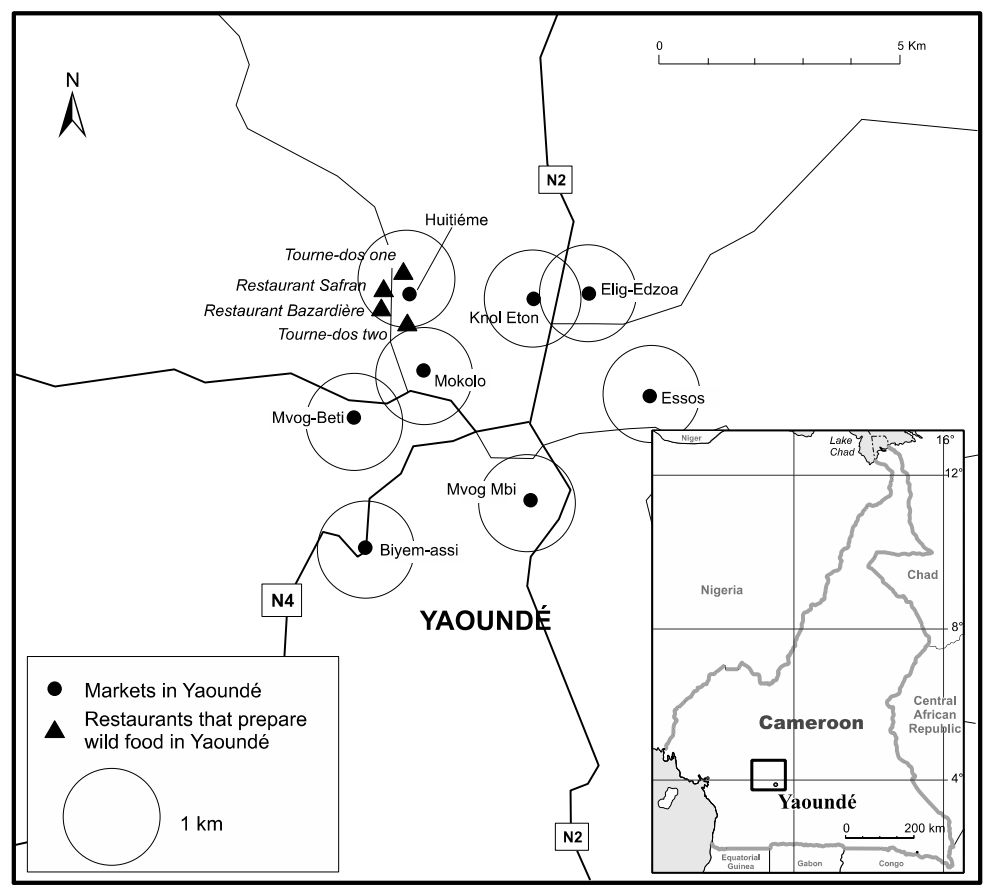

Figure 2. Map of households and markets Limbe and Buea.

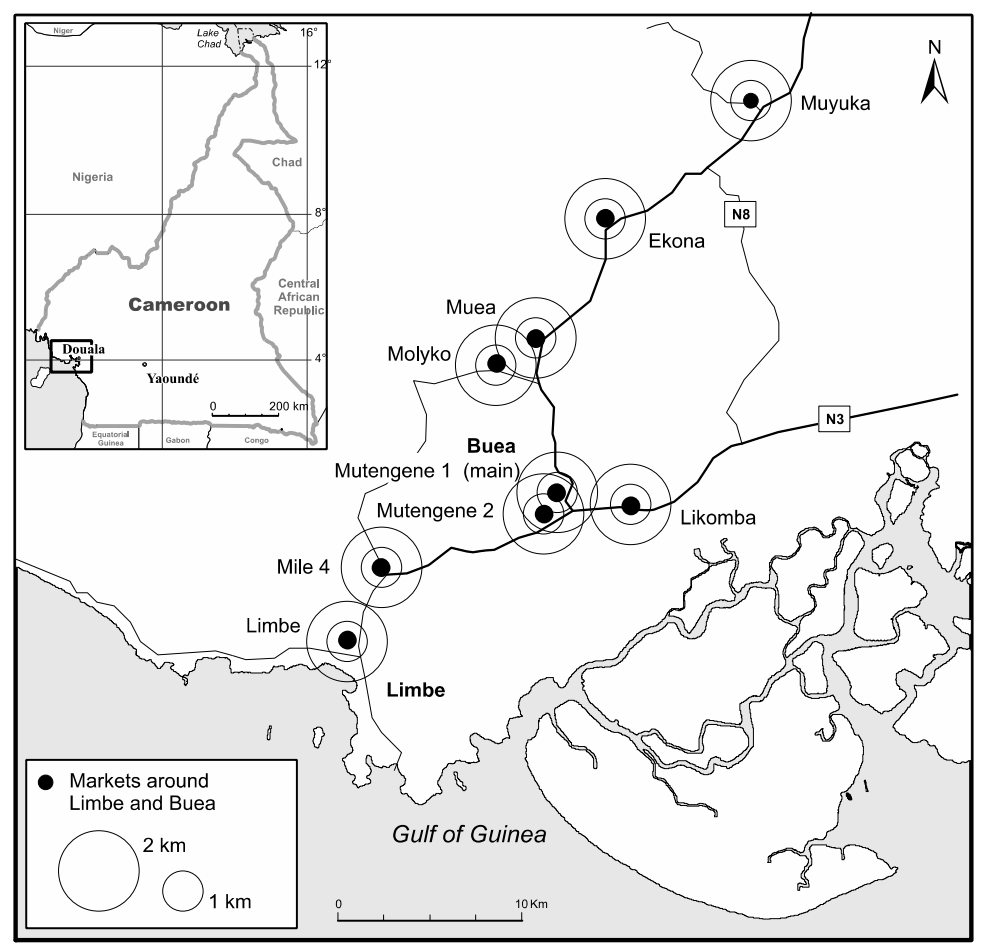


Using these maps, data was collected via participant observation and semi-structured interview surveys in English and French in both markets and households [41,109-114]. The surveys were conducted in both the wet and dry seasons. The author relied on the capabilities of research assistants who were competent in either English or Cameroonian Pidgin (for interviews in Buea and Limbe) or French (for interviews in Yaoundé the capital). Individuals were randomly selected in the market and asked to participate in the study. These included food traders in the market and customers looking to fulfill their food needs. Randomly selecting participants ensured diversity in the sample and allowed for an analysis of the particularities of urban sub-Saharan Africa food markets.

The households that were interviewed typically do their food shopping in the markets falling within a one to two kilometer radius from their home. Reasons given for choosing certain markets were: diversity of products, proximity to their home and price. Some markets have a reputation for particular food products and in all cities individuals commonly frequent more than one market to locate certain products. One woman in Yaoundé mentioned: "Huitieme for tomato and green condiments, garlic, Mokolo for big items and Mvog-Ada for meat, smoked fish, plantain and fruits." Designing the research in this way allowed for ethnographic insights into urban food markets, and also food purchasing patterns and trends of households [115,116].

The survey was field tested in each city for reliability. The interviews were guided mostly by open-ended questions, including: where do you do your food shopping? What percentage of your monthly income do you spend on food? What do you do when you don't have enough food, and don't have enough money to buy food? What foods do you need to feel food secure? During these field tests the survey became participatory as additional questions were added or omitted based on preliminary responses and input from participants [117-119]. The questions deemed most sensitive were related directly to income and also to foods that were considered "rich" food or "poor" food. Questions about income were reduced to focus specifically on the portion of the household budget related to food. Framed in this way, participants were comfortable sharing portions of budgets without worry that a "tax man would come by." In Yaoundé 106 food traders and 127 households and in Buea and Limbe 64 food traders and 70 households participated. In total, this study is based on interview survey data from 197 households, 170 food traders and four women who run open-air restaurants: 371 participants in total. When factoring in dependents and household size, the survey includes 2,111 individuals. Participant observation in the food markets and also shopping and cooking with some households also inform the study.

Special attention was given to the types of wild foods consumed, if any, and the impact of food prices on households' budgets. Data was stratified by gender (male and female headed households) and income level (low, middle, and high). Qualitative measurements of food security include indirect indicators (e.g., asset ownership, social support networks, household size, and immediate circumstances), food coping strategies (e.g., household attempts to deal with times of insecurity through dietary changes, rationing consumption, establishing credit, drawing on social networks, etc.) and perceptions of acceptability (e.g., symbolic role of food and cultural appropriateness within the household) [120]. Table 1 characterizes the data by age, gender and reported class based on employment, income, and assets The data predominately represents middle class $(64.6 \%)$ females $(85.5 \%)$ between the ages of 20-40 (53.7\%). 
Table 1. Characterization of survey data by age, gender, class.

\begin{tabular}{ccccccccc}
\hline $\begin{array}{c}\text { Interviews } \\
(\mathbf{n}=\mathbf{3 6 7})\end{array}$ & $\begin{array}{c}\text { Total } \\
\#\end{array}$ & $\mathbf{\%}$ & $\begin{array}{c}\text { Interviews } \\
(\mathbf{n = 3 7 1 )}\end{array}$ & $\begin{array}{c}\text { Total } \\
\#\end{array}$ & $\begin{array}{c}\text { Households } \\
(\mathbf{n}=\mathbf{1 9 7})\end{array}$ & $\begin{array}{c}\text { Total } \\
\#\end{array}$ & $\%$ \\
\hline Age $<20$ & 3 & 0.8 & Male & 54 & 14.5 & Poor & 44 & 22.6 \\
Age 20-40 & 197 & 53.7 & Female & 317 & 85.5 & Middle & 126 & 64.6 \\
Age 40+ & 135 & 36.8 & & & & Rich & 16 & 8.2 \\
No answer & 32 & 8.7 & & & & No answer & 9 & 4.6 \\
\hline
\end{tabular}

A gender imbalance exists between men and women as regards the selling of food, food provisioning and cooking in households in the Congo Basin. This includes buying and cooking food, getting water from a public source in the city and also obtaining fuel (wood, gas, sawdust) to prepare food. From the survey, it was learned that women cook foods with their daughters, and sometimes sons, but their husbands do not assist in food preparation unless the wife is out of town or sick. Cooking at home is the predominant way of feeding the household as it is considered expensive to eat out. The households surveyed rely on domestic, public or community, together with stream and river sources for cooking and drinking water. Fuel sources for cooking range from firewood, gas, sawdust, coal and charcoal and while the cost of these items are factored separately into food budgets and because of the expense they are used frugally for cooking.

Survey data, transcripts and field notes from interviews and discussions were read and coded for emerging themes related to wild food consumption and relative levels of food security within and between households at different income levels. There was a particular focus on the perceived acceptability of these foods for meeting household needs. It uses textual and illustrative means to explain reasons for varying circumstances and experiences of engaging with wild food products. The author makes no claim from this case study that data are representative of the wider populations of these cities or quantitative rates of food insecurity in these cities. Instead, the data represents a snapshot into the lived and daily realities of food provisioning for residents of Yaoundé, Limbe and Buea.

\section{Results}

The results in this section seek to answer the central research outlined above in the introduction and speak to De Schutter's [24] three dimensions of food security: availability, accessibility and adequacy.

\subsection{Availability}

Data collected for this study show that 66 wild foods were named and available in city markets in southern Cameroon (identified in Figures 1 and 2) the most frequently named include: bush mango (Irvingia spp.), njansang (Ricinodendron heudoletii), Rondelle (Scorodophloeus zenkeri Olom) Cola acuminata; Cola pachycarpa K.; Cola nitida (bitter kola, monkey kola, red kola), African cherry (Prunus Africana), country onion (Afrostyrax kamerunensis/Afrostyrax lepidophyllus), alligator pepper (Afromomum melegueta), safou or bush plums (Dacryodes edulis), egusi melons (Cucumeropsis edulis) honey, leafy vegetables such as eru or okok (Gnetum africanum), and several species of bushmeat, mushrooms, termites, forest snails, and caterpillars (see Table 2 for a list of the most 
commonly identified foods). These foods can be categorized as spices, condiments, proteins, aphrodisiacs, medicines, and vegetables.

In terms of availability, wild foods do not fit into De Schutter's standard agricultural model. These foods do not necessarily require access to agricultural seeds, technological inputs, fertilizers or pesticides. The supply-side of wild food hinges on a different set of factors and production knowledge that influences availability such as seasonality, weather, harvesting or gathering and most importantly access to the forest. The climate in Cameroon's forested southern region is described as "four seasons equatorial" [121]. This includes a clearly defined major dry season (December-May), followed by a short rainy season (May-June). The short dry season lasts from July-October followed by a high rainfall wet season (October-November) [122]. What are noteworthy about the availability of wild food products are the seasonality of particular foods and the identification of peak periods of abundance and also scarcity. For example, due to seasonality, there are times when markets are full of safou. In June and July the deep purple fruit with avocado-colored insides are available by the piles in urban markets. In addition to being sold raw for home consumption, plums are also prepared on the roadside, by women fanning small fires, roasting the plum for a quick snack or meal on the go. Safou plums often replace maize roasted roadside as the seasons change.

Table 2. Wild foods most commonly identified and available in Cameroonian cities, peak periods of abundance, and uses.

\begin{tabular}{|c|c|c|}
\hline Wild food & Peak periods of abundance & Use and Preparation \\
\hline $\begin{array}{l}\text { Eru/okok (Gnetum } \\
\text { africanum) }\end{array}$ & $\begin{array}{l}\text { All year, but more in the } \\
\text { rainy season }\end{array}$ & $\begin{array}{l}\text { Sliced thinly and cooked in a stew with } \\
\text { waterleaf, cow skin, dried fish and crayfish } \\
\text { and palm oil and eaten with cassava } f u f u\end{array}$ \\
\hline Bush mango (Irvingia spp.) & $\begin{array}{l}\text { July and August and } \\
\text { September and October }\end{array}$ & $\begin{array}{l}\text { Fruit is popular for children; stone is dried } \\
\text { and ground down and used as a soup thickener }\end{array}$ \\
\hline $\begin{array}{l}\text { African plums, safou } \\
\text { (Dacryodes edulis) }\end{array}$ & April-October & Fruit is boiled or roasted before it is consumed \\
\hline $\begin{array}{l}\text { Kola (Cola acuminata; Cola } \\
\text { pachycarpa K.; Cola nitida) }\end{array}$ & August-September & Chewed when drinking palm wine; stimulant \\
\hline $\begin{array}{l}\text { Njansang } \\
\text { (Ricinodendron heudoletii) }\end{array}$ & May-September & $\begin{array}{l}\text { Dried and prepared in a soup; can be substituted } \\
\text { for groundnut in soups and stews }\end{array}$ \\
\hline $\begin{array}{l}\text { Bush onion or country onion } \\
\text { (Afrostyrax kamerunensis/ } \\
\text { Afrostyrax lepidophyllus) }\end{array}$ & July-August & $\begin{array}{l}\text { Used in soups and stews as a condiment or } \\
\text { spice, especially in ekwang. }\end{array}$ \\
\hline $\begin{array}{l}\text { Mbongo } \\
\text { (Aframomum citratum) }\end{array}$ & May-September & $\begin{array}{l}\text { Roasted until charred then ground and } \\
\text { mixed with other spices usually for a fish } \\
\text { soup (mbongo tchobi) }\end{array}$ \\
\hline $\begin{array}{l}\text { Rondelle (Scorodophloeus } \\
\text { zenkeri Olom) }\end{array}$ & All year & $\begin{array}{l}\text { Seeds and bark from the tree are eaten after } \\
\text { simple drying. Pulped or ground, they have a } \\
\text { flavor similar to garlic and are used as a spice } \\
\text { in cooking }\end{array}$ \\
\hline $\begin{array}{l}\text { Alegata pepper } \\
\text { (Afromomum melegueta) }\end{array}$ & $\mathrm{n} / \mathrm{a}$ & $\begin{array}{l}\text { Used in soups and stews and holds cultural } \\
\text { significance to ward off evil spirits }\end{array}$ \\
\hline
\end{tabular}


Table 2. Cont.

\begin{tabular}{|c|c|c|}
\hline Wild food & Peak periods of abundance & Use and Preparation \\
\hline $\begin{array}{l}\text { Pebe (Monodora myristica } \\
\text { (Graertm.) } \\
\text { Dunal African nutmeg }\end{array}$ & $\mathrm{n} / \mathrm{a}$ & $\begin{array}{l}\text { Seeds from the tree are dried and sold whole } \\
\text { or ground to be used in stews, soups, cakes } \\
\text { and desserts }\end{array}$ \\
\hline $\begin{array}{l}\text { Quatre cote } \\
\text { (Tetrapleura tetraptera) }\end{array}$ & $\mathrm{n} / \mathrm{a}$ & Spice for stews \\
\hline $\begin{array}{l}\text { Caterpillars } \\
\text { (Rhynchophorus phoenicis) }\end{array}$ & June-July & Roasted and or dried for soups and stews \\
\hline Termites & March-September & Protein, dried and roasted \\
\hline Mushrooms (several species) & Rainy season & Protein, prepared in a stew \\
\hline $\begin{array}{l}\text { Forest snails } \\
\text { (several species) }\end{array}$ & Rainy Season & $\begin{array}{l}\text { Protein, prepared in stews and also boiled } \\
\text { and roasted }\end{array}$ \\
\hline Honey & All year & Medicine, food, gift \\
\hline $\begin{array}{l}\text { Bushmeat (various, } \\
\text { including antelope, snake, } \\
\text { cane rat (Thryonomys) and } \\
\text { pangolin (Manis tricuspis) }\end{array}$ & All year & $\begin{array}{l}\text { Protein, prepared from fresh, roasted or } \\
\text { dried to be used in stews }\end{array}$ \\
\hline
\end{tabular}

When there is scarcity, food traders or buyam-sellams (in Cameroonian Pidgin) named various reasons for low stocks of wild food in the market. Some traders say: "It depends on the season. There are periods when there is little harvest from the forest. There could [also] be shortages because of the weather or a rise in prices." Urban residents say the forest is too far away now so they do not go there as much as in the past to find food for their households and for sale. These same residents also suggest that the farm is more reliable than the forest for food harvests because the forest is changing. Other traders herald, "sometime the buyam-sellam don't find the products in the forest and if they do the Forest and Fauna officers [can] stop or arrest the buyam-sellam on the road." Interestingly, some traders mention that, "at times I hear that some people hide food to cause scarcity but this is difficult for perishable foods." These buyam-sellams highlight the difficulties in maintaining a reliable stock for the urban demand for forested foods.

Due to large scale logging, the growth in cities, decaying roads and voracious officers from MINFOF (Ministère des Forêts et de la Faune) or the police, many wild food traders are finding it less profitable to travel to the forest to gather food for the cities. This impacts the availability of these products. I often heard complaints from traders that their biggest problems finding food for the market are because of threats of seizure of products by officers or the bothersome possibility of paying bribes to ensure the food arrives at the market. The possibility of a shake down is most often an opportunity for corrupt officers to "chop" the earnings of gatherers and wholesalers, and not necessarily related to the traders going against a law. Efforts by the government to halt corruption are underway and may trickle down to roadside police.

The most notable wild foods found in urban markets are the spices (see Figure 3). Cameroonian cuisine combines the different regional staples (such as rice, yams, cocoyams, plantains, potatoes, cassava, maize and millet) with vegetables, fruits, and animal and fish products into a soup or stew. The staples are usually roasted, boiled, fried or pounded in a mortar. The most common are plantain, cassava and cocoyam, which when pounded takes on a gelatinous consistency as the starch breaks 
down [123]. The resulting fufu accompanies one-pot dishes, such as ndole, eru or okok, achu vegetable, kwakoko with mbanga soup and mbombo djobi (or mbongo tchobi), among other local meat and fish dishes and are exceptionally popular ([124], p. 139). Figure 3 identifies most wild spices available in Yaoundé during the wet season. These spices include various parts of a plant such as the fruits, the stone or pit of fruits, the bark, the blossoms and leaves and bulbs. These parts are dried and often ground into a powder or a paste. For example, the pit of the bush mango when dried and ground to a crumbly paste is added to stews as a thickener. The ground pit creates a slimy consistency, similar to okra that facilitates eating the stew with the accompanying $f u f u$, which is eaten by hand. While many edible wild plants and other food products are regularly included in local food purchases, wild spices make up a significant portion of the household food basket and are inextricably linked to the food culture. These spices are components of recipes that are a part of traditional meals and the daily diet. Often I heard the argument, "if we do not have food from the forest, we cannot make our traditional meals and they are my children's favorite foods." Cameroon is made up of over 250 ethnic groups and the cuisine differs not only by ethnic group, but also by region [125]. Foods from the forest are essential components for these dishes and the regional cuisine. They also provide important vitamins and minerals derived from dietary diversity that help to keep households healthy. The spices pictured (in Figure 3) are some of the spices, in various forms, that are available for these meals.

Figure 3. Image of wild spices collected from markets in Yaoundé.

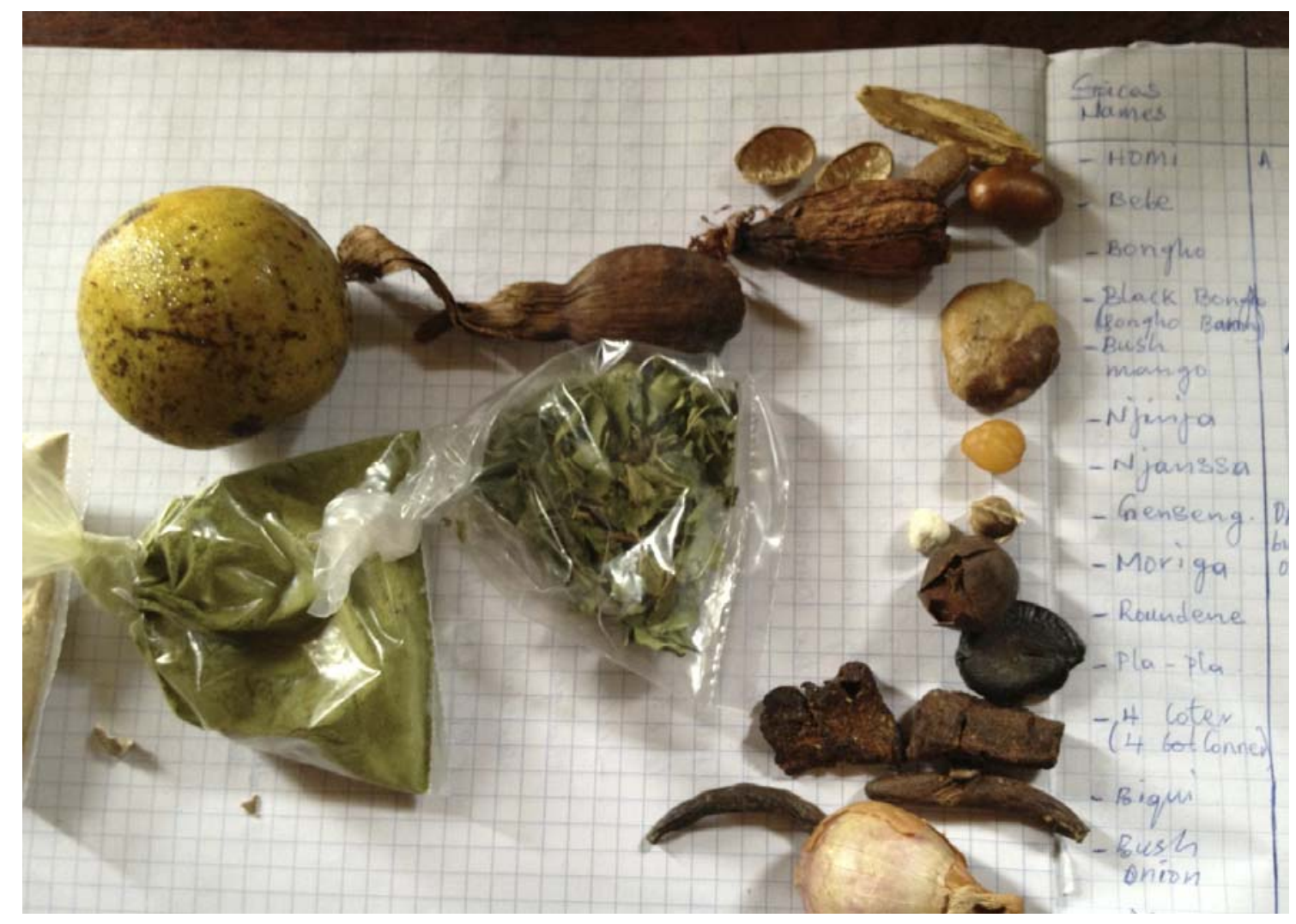

\subsection{Over-Exploitation}

Certain wild foods are in high demand and are considered threatened by organizations such as the International Union for the Conservation of Nature (IUCN) and the World Agroforestry Centre 
(ICRAF). To mitigate the effects of over-exploitation, some wild foods are undergoing cultivation, which is the process of growing and managing wild species through selection and adoption of desirable characteristics [126]. The cultivation initiatives, for Gnetum, bitter leaf, njansang, country onion, and cane rat (Thryonomys) and snails help to ensure these foods are available in times of scarcity and inconvenience while also managing the damaging effects of overharvesting. These initiatives help to ensure their availability through sustainably managing the wild population to avoid over exploitation of the forest. One example is the wild leafy vegetable, Gnetum africanum, which is a climbing vine and can be successfully propagated. The leaves of the vine are edible and are sliced thinly, to help break down the tough leaves (Figure 4). Bundles of eru are available in city markets and results from the survey show that eru with waterleaf and $f u f u$ was overwhelmingly named as the household's most favorite dish. Eru or okok (as Gnetum is known in English and French Cameroun) was mentioned 914 times in the survey of 371 individuals. One woman confessed "If I don't eat eru I feel like I have not eaten". While cultivation efforts ensure that harvests are not depleting wild populations of the food products, the health benefits derived from consuming these foods and consumer demand make endeavors such as these worthwhile (see the section on adequacy below).

Figure 4. Bundles of Gnetum spp, sliced gnetum and palm hearts in a market in Yaoundé.

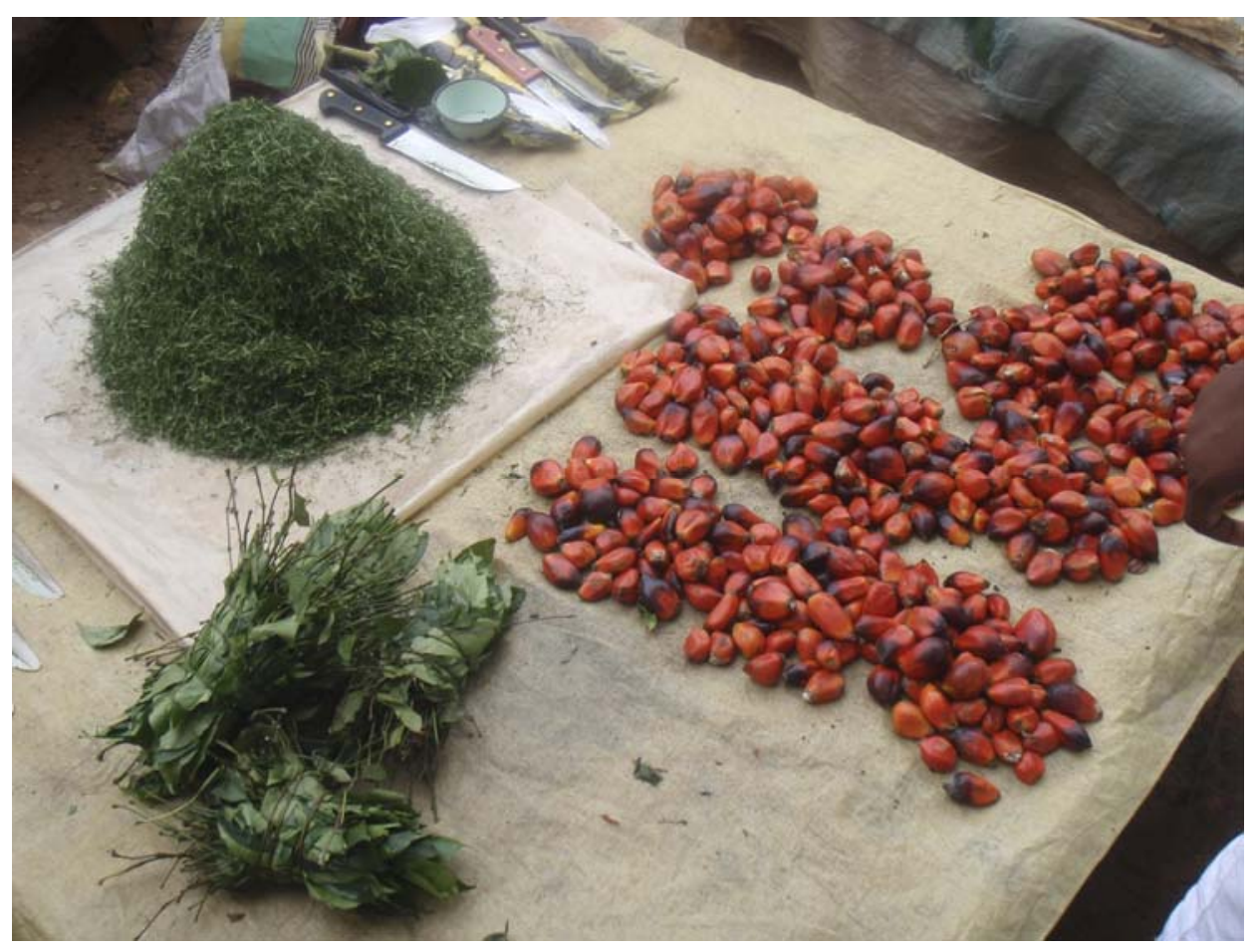

\subsection{Accessibility}

There is a confluence of factors that impact food accessibility for urban households. According to De Schutter, accessibility "requires both physical and economic access: physical accessibility means that food should be accessible to all people... economic accessibility means that food must be affordable without compromising other basic needs such as education fees, medical care, or housing" ([24], p. 4). In terms of accessibility, the survey revealed that it is "not easy for the poor man in the city to eat." In this case, the individual was speaking about himself, but this quote exemplifies the experience of 
most city residents. From the data gathered in Cameroonian cities, the majority of urban residents spend more than half of their income on food-about 50\%-75\%. This does not leave much room in a budget of "other basic needs" as highlighted by De Schutter. What is remarkable from this number, is that $25 \%$ of the household's food budget is spent on wild foods. Figure 5 shows how food budgets are broken down by the total amount of income spent on food, and of the total percentage, the percentage of income that is devoted to wild food purchases. The seasonal variations suggest that more money is spent on wild foods during the dry season than the wet season. This can be attributed to a change in prices in the market, which is described below.

The prices listed below (Table 3) are based on measurements and quantities that vary between buyam-sellam and are difficult to estimate. These prices are directly out of the survey from households and traders, however, the quantities are difficult to compare across product, season and city. Prices and quantities are negotiated between the buyer and seller and can change remarkably from one sale to the next. This table is meant to provide some insight into wild food prices and is not definitive or exhaustive. What is notable from this price data is that there is a slight price difference between cities whereby Yaoundé is seemingly cheaper than Buea and Limbe for forest foods. Additionally, the quantities dramatically change between seasons and prices remain nearly the same.

Figure 5. Percentage of food budget spent on wild food.

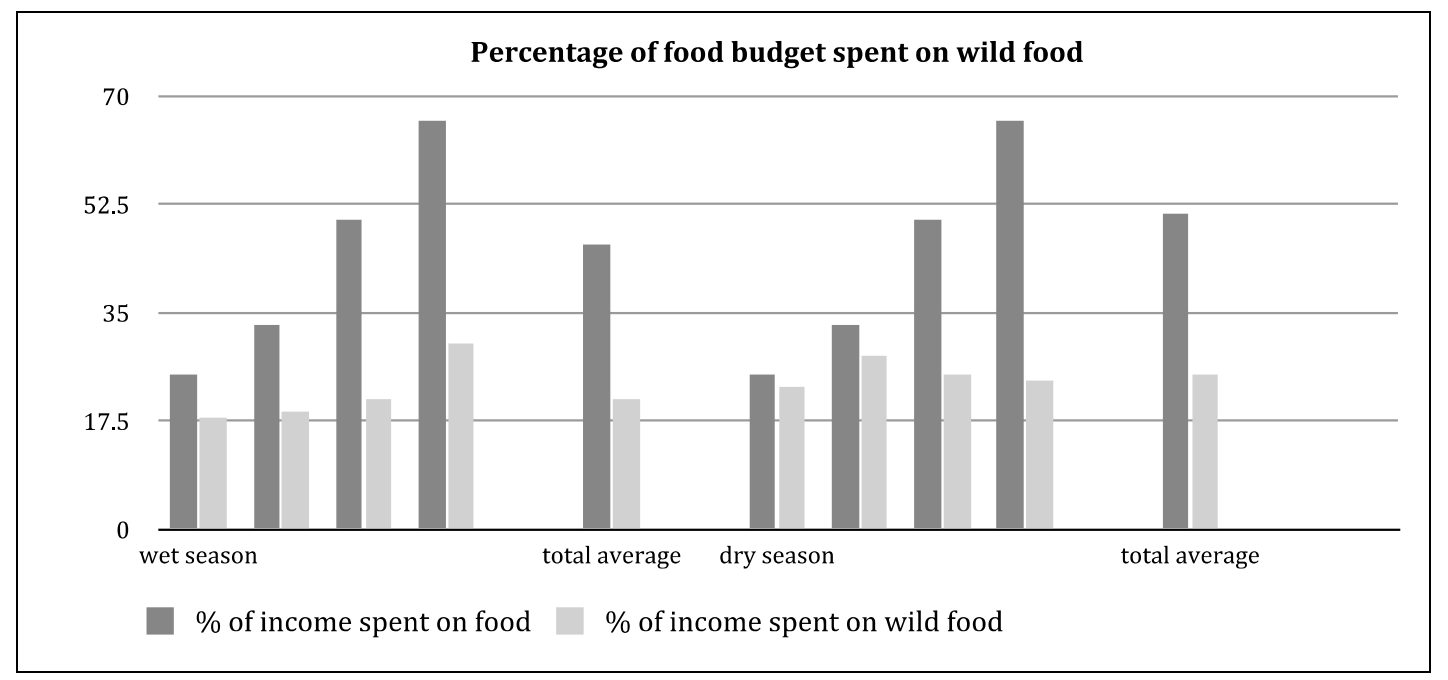

Table 3. Examples of wild food prices in FCFA by city and season $(1 \mathrm{FCFA}=€ 0.0015)$.

\begin{tabular}{|c|c|c|c|}
\hline $\begin{array}{l}\text { Wet season price } \\
\text { Yaoundé }\end{array}$ & $\begin{array}{l}\text { Dry season price } \\
\text { Yaoundé }\end{array}$ & $\begin{array}{l}\text { Wet season price Buea } \\
\text { and Limbe }\end{array}$ & $\begin{array}{l}\text { Dry season price Buea } \\
\text { and Limbe }\end{array}$ \\
\hline njansang/50-100 cup & njansang/50 smallest cup & njansang/250-400 cup & njangsang/350 glass \\
\hline bush mango/50 a cup & bush mango/100 a cup & bush mango/200-800 cup & bush mango/500 glass \\
\hline okok/100 cup & okok/50 smallest cup & $\mathrm{eru} / 12002 \mathrm{~kg}$ & eru/1200 $3 \mathrm{~kg}$ bundle \\
\hline rondelle/50-100 cup & $\begin{array}{l}\text { rondelles/25 for two } \\
\text { cloves (gousses) }\end{array}$ & $\mathrm{n} / \mathrm{a}$ & $\mathrm{n} / \mathrm{a}$ \\
\hline mushrooms/100-200 cup & mushrooms/150 a head & mushroom/250 glass & $\mathrm{n} / \mathrm{a}$ \\
\hline termites/100 cup & termites/ 25 the smallest box & $\mathrm{n} / \mathrm{a}$ & $\mathrm{n} / \mathrm{a}$ \\
\hline mbongo 50-100/cup & mbongo/25 for $1-2$ cloves & $\mathrm{n} / \mathrm{a}$ & $\mathrm{n} / \mathrm{a}$ \\
\hline bushmeat $/ 5000$ & bush meat $/ 7000$ & wild game $/ 30002 \mathrm{~kg}$ & wild game $/ 30001 \mathrm{~kg}$ antelope \\
\hline snails/100-200 cup & snails/75 for one & snails $/ 500$ for $1 / 4 \mathrm{~kg}$ & snails/700 $1 / 4 \mathrm{~kg}$ \\
\hline
\end{tabular}


When it is the wet season, food traders describe a change in the amount of wild food they sell. During the wet season in Yaoundé 94\% of traders claim they sell more as compared to 78\% of traders in the dry season claiming they sell less. Reasons given suggest various urban trends such as an increasing urban population because clients are increasing and creating a rise in demand. Traders report selling less in the dry season, suggesting that "there is competition, sales are declining, business is difficult" and "the clients complain about the financial crisis and they reduce the quantity and the frequency of purchases". While all of these reasons are likely, one way to describe the fluctuations amongst sales between seasons is linked to physical availability: when there is scarcity or the perception of scarcity, some sellers raise their prices. When these foods are perceived to be abundant some traders lower their prices, making these foods more economically accessible. On the other hand, some traders in the context of abundance after the rainy season will leave prices unchanged. Instead, they will increase the quantity of foods they sell while keeping prices the same as dry season prices. The perishability of these foods often encourages traders to pursue this pan-seasonal pricing strategy.

In this context, when asked if eating habits change between seasons, all households said that "Yes they change. We adapt for each season. We eat what the vendors have that is least expensive and abundant in the market" and "During the dry season there are many shortages and we make do with what is least expensive. During the rainy seasons a lot of products are less expensive and are varied." This change in quantity impacts consumers in various ways. Food buyers are forced to change their food provisioning patterns between seasons as people report buying and eating less food during the dry season. When consumers reduce the quantity and frequency of their purchases in the dry season, the buyam-sellam have already decreased the size of the quantity that would be sold from the season before. A fluctuation in food intake on this scale has an impact on diet and health. One trader in Yaoundé remarked, "I think that they [my clients] eat less. They just look to eat, not to have a balanced diet." Seasonality is a major factor for food insecurity in urban areas across Africa and compounded by climate change, the struggle for calories could be greater in the future.

When asked the question: do you buy and consume wild foods in your household in function with the level of your revenues? Most women answered with a resounding no. Women in Yaoundé, Buea and Limbe assert that these are products we buy because we like to eat them. Most women mentioned, "They are not expensive. They are accessible to all and we buy them because they are necessary in the preparation of our meals." Taking this further, one women asserted, "we consume them only as a question of taste and want, (not need); these foods are a part of our culture it is only because of their flavor that we eat them." One single-woman with four dependents said "certainly we don't have enough money, but we eat more foods from the forest because we have adopted them in our eating habits." Identifying these foods as something that contributes to and enables a more robust food culture, the purchase of wild foods means something more than just buying and eating these foods.

When asked if food stability in your household is disrupted when there is scarcity or increased prices for wild food products, many participants in the survey answered with a resounding yes. The most common answer being: "our favorite household dish uses forest foods as its base and we use it as the principal condiment in certain dishes." Similarly, most women mentioned, "our eating habits revolve around these products." Other women mentioned the need to substitute food items and to change planned meals. Often this means abandoning the established diet and incorporating more cheaply available and often imported foods: "I would be forced to eat other products because when there is a 
rarity of NTFPs I eat other things like sautéed pastas." The effect a price rise of wild food has on diets does not go unnoticed, another woman revealed "I could no longer eat a balanced diet I will be forced to eat spaghettis [sic] and fried rice without my favorite condiments." Still another woman claimed "if some foods become rare we eat something else, they are important but we can do without them." The ability to substitute foods and have flexible food options are a feature of urban diets, but the frequency in which this needs to happen does have an effect on dietary diversity and health.

Before the 2007-2008 food crisis a common narrative from Cameroon was that imported products were generally more expensive than local foods and crops. These imported foods relied on more formalized trade networks than traditional organizations that managed production and distribution and were known to be cheaper ([104], p. 189). When asked which imported food products are more available to you than local products, the greatest frequency in the response was rice, pasta, fish, and sardines. Households in Yaoundé described these products as being "available to everyone, they are less expensive than local products." In cities in Cameroon the food price crisis has had a strong impact on households' food security. In this case, there were also price fluctuations in the market for local food items and this can often influence and initiate an adjustment in food provisioning patterns.

A very revealing question from the survey highlighted a difference between cities as regards foods consumed in households in the last 12 months. As part of the survey, participants had four choices to choose from in their answer: we always have enough to eat and the kinds of foods we want; we have enough to eat but not always the kinds of foods we want; sometimes we don't have enough to eat; and often we don't have enough to eat. Results from this question show that households in Buea and Limbe have enough food to eat, but not the kinds of foods they want; whereas residents in Yaoundé say that sometimes we do not have enough to eat (Figure 6).

Figure 6. Affirmations that describe the food consumed in a household in the last 12 months.

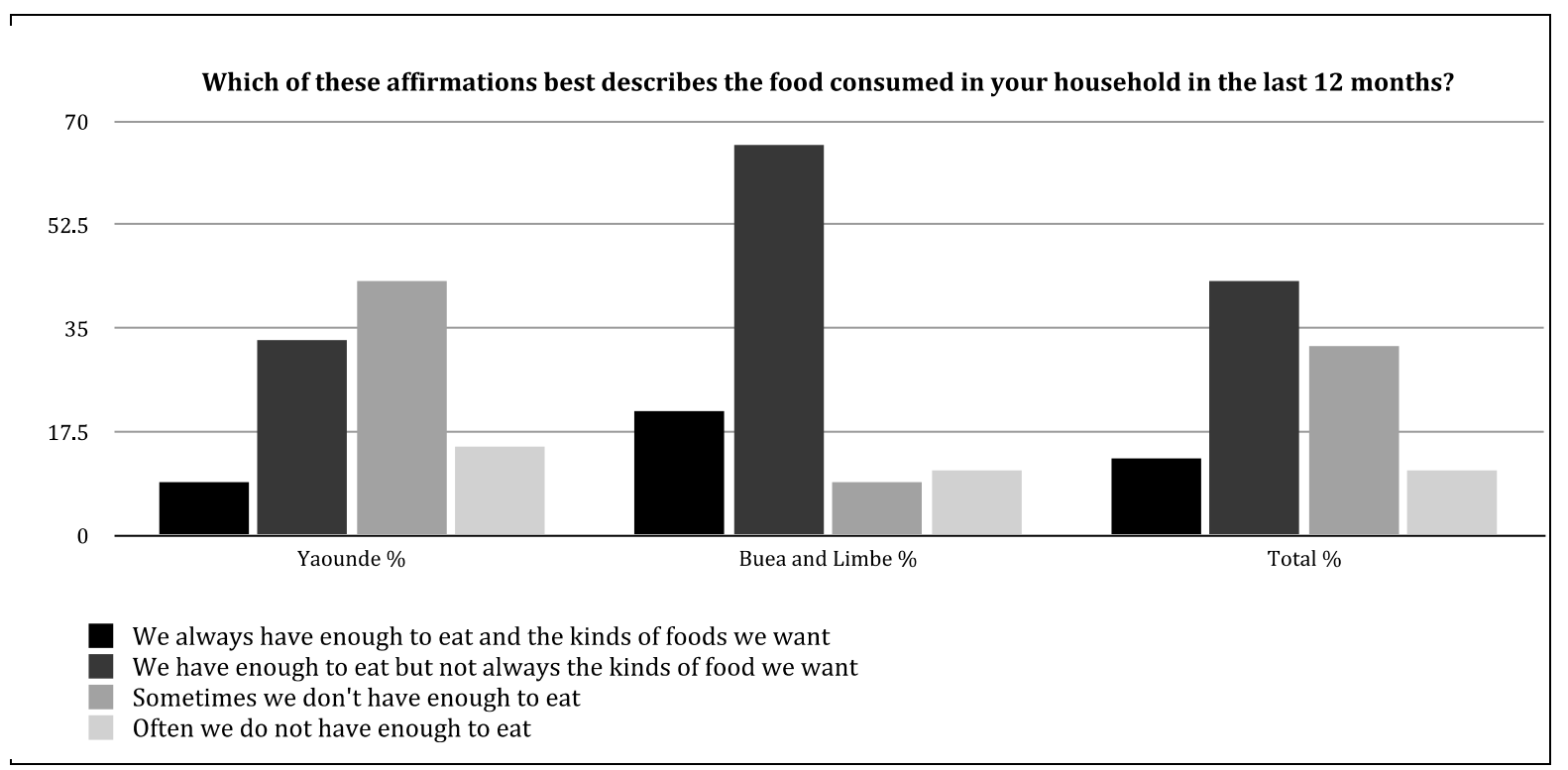

There are a few ways to interpret the responses in Figure 6. Linguistically, there is a divide in Cameroon between the English-speaking western region and the rest of the French speaking country. Residents from Yaoundé, the French capital may enjoy lower prices and greater access to foods than their Anglophone counterparts. While the Anglophone cities are closer to the Francophone city of 
Douala, the main port for the region, than the capital, responses such as these could stem from the "Anglophone Problem" in Cameroon [127]. This problem is "fundamentally institutional and economic" and is best described through the ways that "state power is exercised in a fractured polity... and how that power is used to benefit one group at the detriment of another" ([127], p. 61). This problem has been well documented, see for example: [127-129]. An investigation into price comparisons (Table 3) between cities and seasons showed that the prices for wild foods were slightly higher in Buea and Limbe than in Yaoundé. In this case, food substitution happens, but it is not always enjoyed. This has to do with the types of coping strategies adopted by many of these households. The differences found between coping strategies adopted in Francophone and Anglophone cities are explored in more detail below.

\subsection{Strategies to Cope with Increasing Prices}

The impacts of price shocks for commonly consumed foods initiated a host of coping strategies. When asked, what do you do when you do not have enough food and do not have enough money to buy food, women often say "we are used to it..." The demand for local Cameroonian food is high; however, accessing that food when prices are elevated is a challenge. When households do not have enough food or enough money to buy food, the most commonly named strategies include:

- I manage with the little I have

- I am stricter about how much food I serve and other than the children we only eat one meal a day

- I make a cheap meal with rice and palm oil or garri (cassava) and water

- I reduce the quantity of food I eat

- I eat one or two meals a day

- I harvest from my farm

- I borrow from family, savings group, or merchant

Statements such as these demonstrate how urban residents adapt to an unrelenting food security situation. In both Anglophone (31\%) and Francophone (25\%) cities residents say they "manage with the little I have". This can last for two days and happens often, at least once a month. The differences in strategies are apparent. In Francophone Cameroon some women mentioned eating cheaper foods more frequently such as fried rice, bread and braised fish by the roadside. They also talked about rationing food and buying and eating smaller quantities (20\%). Reducing the number of meals eaten in a day was the most common answer for Yaoundé residents (28\%). Reducing the number of meals was also mentioned in Buea and Limbe (23\%). Whereas in Anglophone Cameroon, the two most common answers were: I borrow from family and relatives (20\%) and I go to the farm to harvest food (20\%). Borrowing from relatives was mentioned by only a few Francophones (9\%) and harvesting from the farm was not mentioned. This can also be attributed to differences in urban food geographies [23]. From these responses, it is safe to assume that most urban residents from the survey are living in a state of food insecurity as "secure access to enough food at all times" is not a statement that describes the current situation [130].

From these data, it can also be learned that eating less meals also means eating less at meals, eating lower quality foods, and eating cheaper options. Responses from the survey show that $54 \%$ of the individuals surveyed consumed only two meals a day (see Figure 7) and if these meals already include dishes that are of low quality and diversity, then nutrition is negatively impacted. This is in contrast to 
the findings from the CFSVA that show that $33 \%$ of individuals surveyed reduced the number of meals eaten a day ([105], p. 7). The figure below shows the percentages of the reported responses and the number of meals eaten in a day. Compared to the CFSVA, these percentages show greater food security challenges in cities than was initially reported.

When prices for foodstuffs are elevated, women mentioned buying in smaller quantities, changing their menu, and making food every two days, for the following two days, based on what is affordable. Without proper cold storage, this strategy is somewhat delicate. When it comes to food prices, those with dependents say, "We still buy particularly what the children like." Other women noted that "I review my budget by not buying certain foods, we buy what is most important and we complain to the vendors so that they explain the situation." These women are forced to adapt. Statements such as: "we still buy but this messes up our budgetary plan a bit. There is an instability that exists" suggest that the food situation in most households surveyed is tenuous at best.

Figure 7. Reported meals eaten in a day in Cameroonian cities.

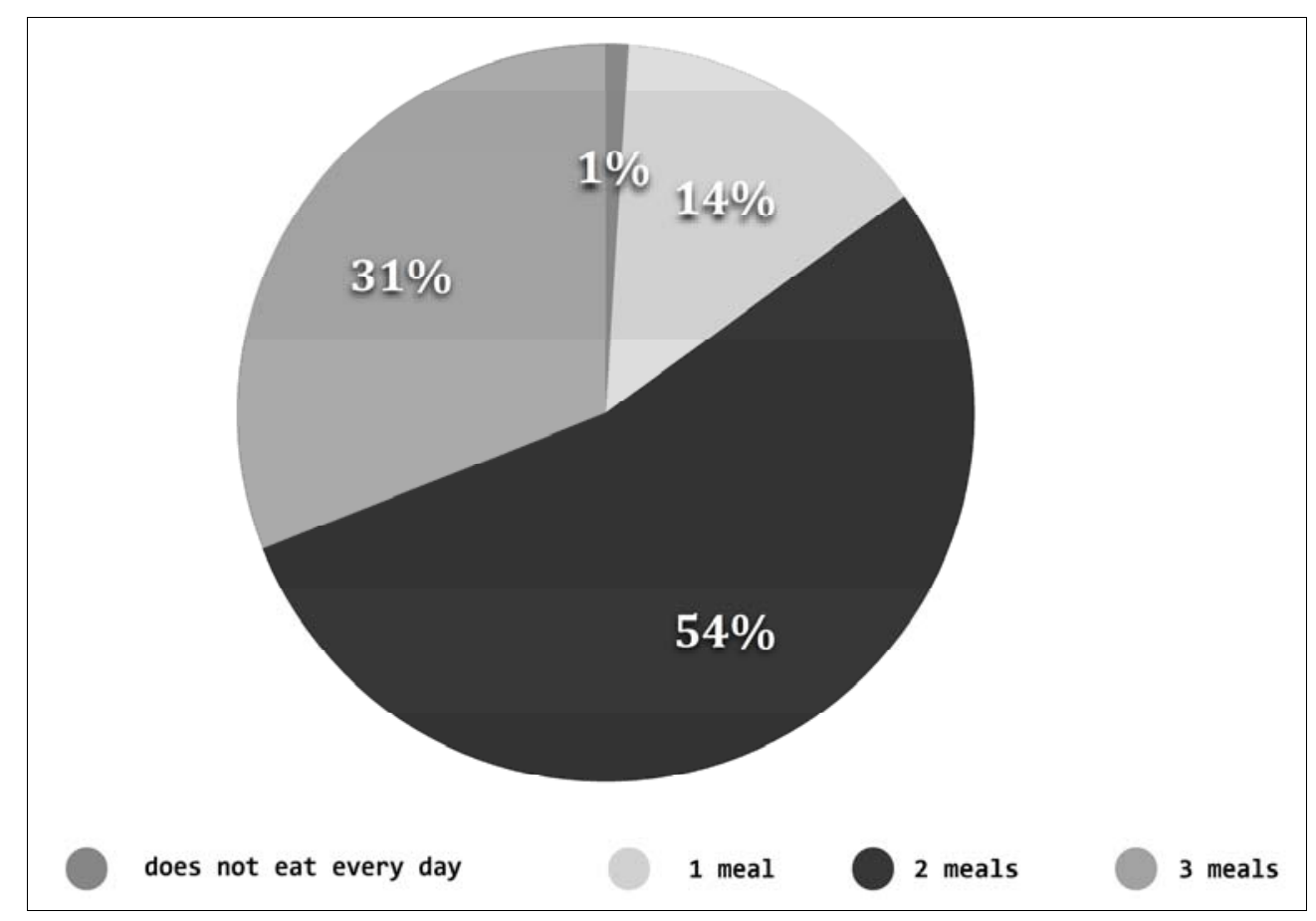

When food prices have risen, the most commonly named foods to buy are: rice, dried beans, pasta, banana and tomato. When prices are low, foods commonly purchased include beef, pork chicken, bar fish, meat generally (and includes bush meat) and plantain. It is important to highlight the distinctions between these lists. The first list includes some foods that are imported and available cheaply, most often, these foods are not impacted by seasons. Having local foods such as banana featuring in this list is interesting because banana is a very ubiquitous tree crop throughout HFZ cities and is a cheaply available fruit. The latter list includes proteins (with the exception of dried beans) which are historically difficult to come by in forested regions [131]. In cities in the forest zone, proteins are still relatively more expensive than the vegetables and staples that traditionally accompany them in dishes. The inclusion of plantains in this list illustrates barriers to access, as the cross-border trade in plantains with Gabon seems to be on the rise. Peppered throughout the market surveys from Yaoundé were stories about the Gabonese coming to the market to buy plantains, driving the prices up $(3,000-7,000$ 
FCFA for a bunch). Banana plantains are an integral part of home cooked meals across the sub-region. On the one hand, Cameroonian households have experienced the price rise as a price shock, forcing them out of the market for a staple food they would prefer to eat. On the other hand, "sharing" the plantain harvest with more affluent Gabonese was a boon for the plantain trader's business.

An increase in food prices is the main shock experienced by urban households, who buy more than $90 \%$ of the food they consume. Eating wild food is often touted as the mechanism to stave of hunger when food shortages are present; however, in cities where wild foods continue to be part of the routine cuisine, these foods can be substituted for less expensive foods with less cultural meaning and less satisfaction. It does not necessarily mean that wild foods are relatively more expensive, rather they are a component of a recipe that may be more expensive to prepare than boiling water for rice and pasta and adding tomato and fish. With this in mind, the discussion turns to the adequacy of food and wild food in cities in Cameroon.

\subsection{Adequacy}

According to De Schutter, adequacy “requires that foods satisfy dietary needs (factoring a person's age, living conditions, health, occupation, sex etc.), be safe for human consumption, free of adverse substances and culturally acceptable" ([24], p. 4). From this list, food safety is a main concern for many urban residents. Many households surveyed in Yaoundé noted that "in the poissonneries the fish is not always fresh but the vendors do not shy away from selling it to the customers." The vendors complain about perishability and mention that the food they sell rots quickly in the rainy season due to dampness, and dries out in the dry season under the sun. Customers are aware of these issues and note particular markets to avoid certain products at different times of the year. Other households disregard the health warning for sustenance. Going back to the frozen chicken scandal example in the introduction, food consumers have to be highly aware of the foods they are buying and eating to avoid what is locally referred to as "running stomach," caused by contaminated foods.

In terms of food satisfying dietary needs and being culturally acceptable, there is an "informal rule" in the Cameroonian cities studied: the less money you have, the more imported rice you eat. Remarkably, a study of the urban plantain sector in 2004 or pre-global food crisis showed that "imported products such as rice or wheat are... generally more expensive than local products" ([104], p. 189). After the crisis consumer sovereignty has been "non-existent in markets where women have faced a "take it or leave it" choice of buying imported rice or nothing at all" [132]. The new "preference" of urban Cameroonians post 2008 for "quick" and "easy" rice is rapidly changing diets. Now imported rice is a daily staple because it is available cheaply (Figure 8). The rice that is imported is the milled white rice, which is devoid of the husk and bran. This often results in a version of rice that is quick to cook, but is low in fiber and vitamins. Cheap rice shifts purchasing patterns of urban households away from traditional, local foods (such as cassava, cocoyam, plantain, local rice and wild vegetables), which are nutritionally more beneficial and Cameroon has a comparative advantage in producing. Older women surveyed are shocked by the frequency at which their younger counterparts prepare and eat rice. To these older women, rice was a special occasion dish, often being served for the Sunday meal or for holidays with chicken.

When asked: how many times do you prepare rice per week, most women stated that they serve rice three to four times, some even claiming they eat rice up to five times a week. The role of rice in the 
alimentation of households was most commonly stated as being "primordial" as "it allows me to make ends meet in difficult times". Other women used adjectives such as "important" and "profound." Almost all households surveyed stated that rice serves "a big place in the household menu, because it is not very expensive, it is accessible and easy to cook, it is the most consumed product in our household." The origin of the rice most commonly consumed is Thailand where the heartier Cameroonian rice is reserved for holidays.

The second "informal rule" is that cultural and culinary history dictates that rice is normally not an accompaniment to dishes made with HFZ wild foods. In Cameroon rice was grown in the grasslands, outside the forest zone and takes on a different culinary history. Most wild foods available in markets throughout the country originate from the forest zone. For example, leafy green vegetables are "mainstays in the diets of rural and urban households across most of Africa" more generally, and are especially important in Central Africa [133-135]. Wild leafy vegetables may be the major source of micronutrients for the majority of resource-poor people throughout the region $[12,71,135,136]$. Traditional leafy vegetables (in particular, Amaranthus spp., Corchorus spp., Solanum spp., Manihot esculenta and Gnetum spp.) on a per unit cost basis supply disproportionate shares of protein, minerals and vitamins [133]. In particular, (Gnetum spp.) when cooked as a dish, is not only high in iron and zinc, it is also a rich source of protein and essential lipids. These greens are particularly important in the supply of iron and vitamin C, which may alleviate high levels of anemia in Central Africa exacerbated by high incidences of malaria. Initiatives are underway in East Africa to make African leafy vegetables (ALV) more accessible to the urban population [137,138]. Lessons learned from this initiative can be useful to places where the environment and diet are welcoming of these foods.

Figure 8. Rice options in a shop along Mile 4, Buea.

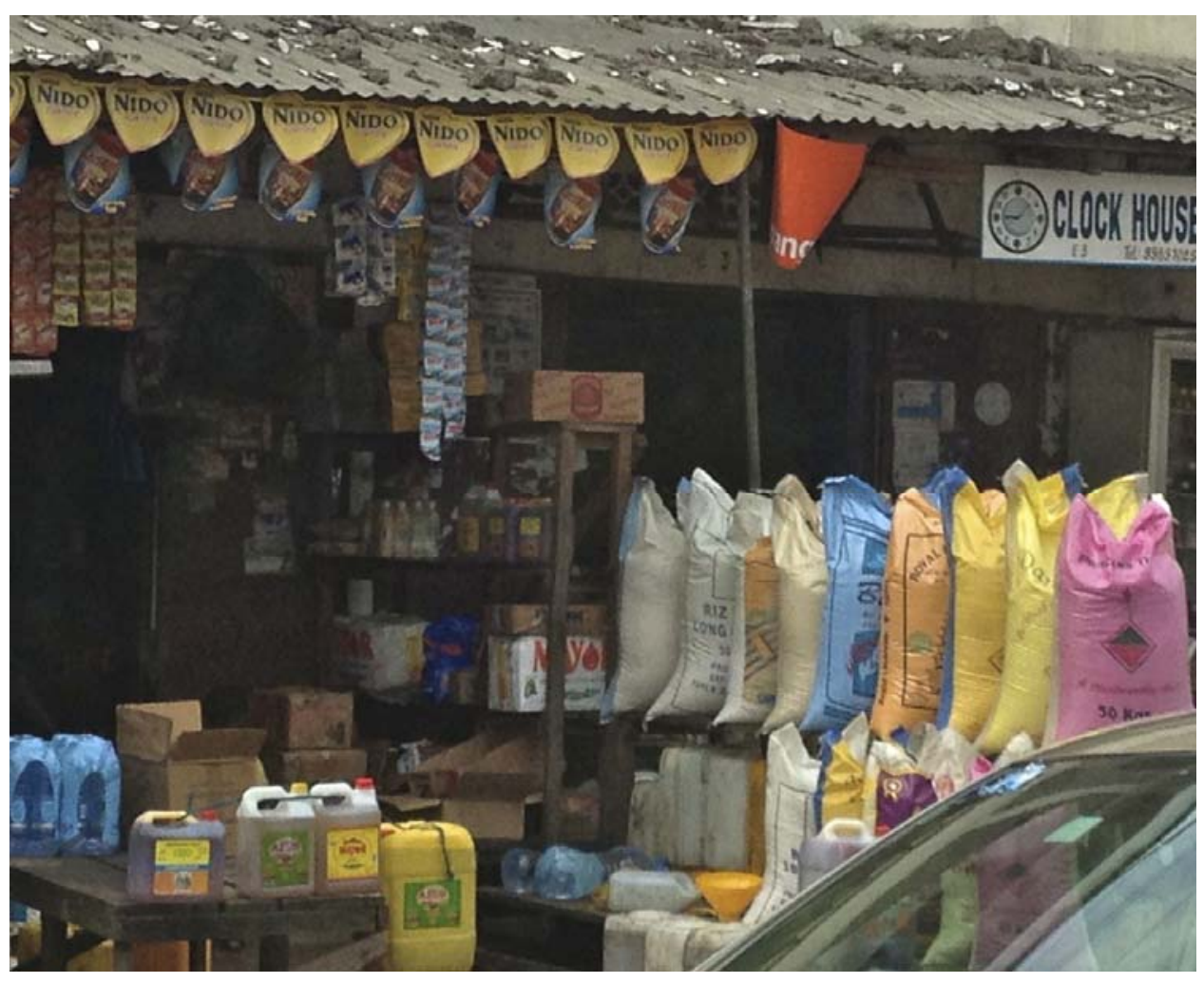


Ethnic group and regional ties do have a role to play in dish composition and accompaniments. Eru or okok (Gnetum spp.) is not served with rice; it goes with miondo, which is made from cassava/manioc, or $f u f u$, which is also made from cassava. Fish mbongo goes with plantain. Njansang sauce with fish goes with plantain. In Cameroon, culture, ethnicity and region command what foods go with what. Agricultural products such as groundnuts and chicken go with rice but these dishes emerged from a different culinary history and one that is more similar to West Africa than Central Africa [123]. Cameroonians enjoy this cultural diversity in their meals and this "informal rule" helps in ensuring dietary diversity. While the nutrition transition has been slower to emerge in Cameroon as compared to other developing countries, the evidence for a nutrition transition in Cameroon is mounting as food prices are affecting the adequacy of diets.

\section{Discussion and Conclusions}

Cameroonians enjoy dietary diversity and the ability to prepare foods from the many regions and ethnic groups that make up the country and fortunately, in urban areas, people come into contact with many of these flavors and culinary histories. However, access to the foods that ensure this diversity is a major barrier and daily obstacle and is driving the nutrition transition. When asked what does it mean to be food secure in Cameroon, most women mentioned affordability and said: "if you have enough money, you will be food secure" and "it means at least the average person can afford for (sic) food." Being food secure means "we can feed our families. But it is very difficult to have food all the time." One woman said: "I think it means having enough to eat at all times and if possible varieties. But most of the time we eat what we have, not what we want." Prices were mentioned in addition to income, "despite everything feeding ourselves remains a major problem, products are expensive and all the households cannot satisfy their hunger" and "life is very expensive in Yaoundé particularly for food; to eat well we are forced to spend too much." Most interestingly, one woman said: "the food basket of each household is becoming more and more meager because life is expensive in our country in general and in the city of Yaoundé in particular." When prompted to offer suggestions to fix this problem participants in the survey overwhelmingly and unanimously mentioned prices and access, and suggested "we need to learn to eat our own products and the Cameroonian state must watch and review the food prices and to act." Finally, one woman responded: "I will end by saying that food products in Yaoundé are expensive, very expensive. A family of four cannot afford to eat manioc at 500/FCFA (USD\$ 1) in one day while it is cultivated here on place." A major theme that emerges from the responses of these women is that the food crisis has priced locally available and nutritious foods out of reach and this impacts the sustainability of nutritious diets in this Central African nation.

This article analyzed the ways that wild foods contribute to the food security of urban households in southern Cameroon. Regarding availability, the study found that at least 66 wild foods were named and sold in the food markets of Yaoundé, Buea and Limbe. The availability of these foods relies on seasons, weather, and access to the surrounding tropical forest. The availability of wild food and wild spices ensures the routine, traditional cuisine. As regards accessibility, the survey and interview data suggest that Cameroonians spend $50 \%-75 \%$ of income on food and that of that figure, $25 \%$ is spent on wild food. The data also found that more money is spent on food in the dry season and eating habits change between seasons. The study also found that many people continue to believe that the accessibility of wild foods is necessary for the preparation of routine meals. Additionally, the study 
found that the food price crisis has had a huge impact on the accessibility of wild foods and also local foods as these foods are increasingly (relatively) more expensive in the context of the government's subsidy scheme. Interestingly, the coping strategies adopted in households differ between Anglophone and Francophone cities. More people in Buea and Limbe do not have access to the kinds of foods they want to eat and in Yaoundé people reported that they do not have enough to eat and eat less frequently. Finally, with respect to adequacy, the data indicate that the less money households have, the more imported rice is eaten (three to four times a week); however, rice is not an accompaniment to dishes made by HFZ wild food. Consequently, high prices are changing diets, as urban residents are part of a global trend towards a nutrition transition.

Through organizing and analyzing the data in light of De Schutter's dimensions a new framework has been applied to understanding wild food, food security, and ultimately sustainability in Cameroon. As his approach is contested, De Schutter's framework is not the only way of knowing about wild foods and food security in this country. That being said, it is an instructive one. Through this lens many uniformities and similarities with respect to the challenges of wild food were identified with the notable exception of the different types of coping strategies that households adopt in the cities of research. Other approaches might yield different results, and further research in other cities on this topic in Cameroon and elsewhere in Africa is called for.

On his 2012 mission to Cameroon De Schutter concluded that the country had made little progress in eradicating poverty and hunger in the last ten years, despite the adoption of poverty reduction measures. He also found regional disparities to be particularly strong [25]. In his view, the sustainability of food chains and food choices has been greatly impacted by the government's inattention to agriculture and food after the oil boom in the 1980s. This inattention was compounded by a series of structural adjustment programs in 1997 and the devaluation of the FCFA. In this environment, the 2007-2008 food crisis has had far reaching effects. Given his recommendations and my findings, it seems appropriate to call for more explicit language in the National Poverty Reduction Strategy Paper, Cameroon's Vision 2025, the Rural Sector Development Plan, and Cameroon's National Food Security Strategy regarding wild and traditional foods. As the government considers eliminating consumer subsidies introduced during the global crisis, Cameroonian consumers face the prospect of higher or more volatile food prices. The elimination of subsidies could force more urban dwellers to pursue coping strategies that push them away from relying on the wild traditional foods they would prefer to eat, and continue to facilitate a dietary transition away from a rich historic source of dietary adequacy. Alternatively, this eventuality could result in an unsustainable return to reliance on "foods from the forest". Regardless of the fallout from subsidy reforms, new and ongoing research needs to be carried out in urban areas on the accessibility of diet rich foods to better understand their contributions to food security, environmental sustainability, nutrition, and public health.

\section{Acknowledgements}

Canada's Social Sciences Research Council (SSHRC) Doctoral Fellowship and Insight Development Grant funded this research. The author wishes to thank the following individuals, for their various contributions to this project: Evan D.G. Fraser, Craig Johnson, Barry Smit, John Smithers, Alice Hovorka, Alexander F. Legwegoh, Kate Parizeau, Spencer Henson, Marie Puddister, Adam Bonnycastle, Matias Margulis, Olufunso Somorin, Florence Munoh, Phil René Oyono, Stella 
Asaha, Akoko Guy Martin Maurice, Serge Kombo Samba, Ngu Arrey Monica, Caleb Yengo Tata, Roland Ndah Njoh, Eugene Loh Chia, Fomeni Anne Christelle, Ashu Augustine Ayuk, Abdou Njida, Ekane Ivo, Mary Nana Nibba, Hubert (Nana), Erin Mailloux, Patrick Wight, the two anonymous reviewers and the hundreds of individuals who shared their food stories and offered a glimpse into their daily lives. Finally, I thank Adam Sneyd, my husband and partner on this research adventure.

\section{References}

1. Pimentel, D.; McNair, M.; Black, L.; Pimentel, M.; Kamil, J. Value of forests to world food security. Hum. Ecol. 1997, 25, 91-120.

2. Grivetti, E.L. Nutritional Geography, History and Trends. Nutr. Anthropol. 2000, 23, 1-16.

3. Herforth, A. Nutrition and the Environment: Fundamental to Food Security in Africa. In The African Food System and Its Interaction with Human Health and Nutrition; Pinstrup-Andersen, P., Ed.; Cornell University Press: New York, NY, USA, 2010; pp. 128-160.

4. Pinstrup-Andersen, P. The African Food System and Its Interaction with Human Health and Nutrition: A Conceptual and Empirical Overview. In The African Food System and its Interaction with Human Health and Nutrition; Pinstrup-Andersen, P., Ed.; Cornell University Press: New York, NY, USA, 2010; pp. 1-13.

5. Kuhnlein, H.; Erasmus, B.; Creed-Kanashiro, H.; Englberger, L.; Okeke, C.; Turner, N.; Allen, L.; Bhattacharjee, L. Indigenous peoples' food systems for health: finding interventions that work. Publ. Health Nutr. 2007, 9, 1013.

6. Tieguhong, J.C.; Ndoye, O.; Vantomme, P.; Grouwels, S.; Zwolinski, J.; Masuch, J. Coping with Crisis in Central Africa: enhanced role for non-wood forest products. Unasylva 2009, 223, 49-54.

7. Malleson, R.; Asaha, S.; Sunderland, T.; Burnham, P.; Egot, M.; Obeng-okrah, K.; Ukpe, I.; Miles, W. A Methodology for Assessing Rural Livelihood Strategies in West/Central Africa: Lessons from the Field. Ecol. Environ. Anthropol. 2008, 4, 1-12.

8. Oyono, R.; Blaise, M.; Kombo, S. Beyond the Decade of Policy and Community Euphoria: The State of Livelihoods Under New Local Rights to Forest in Rural Cameroon. Conservat. Soc. 2012, 10, 173-181.

9. Scoones, I.; Melnyk, M.; Pretty, J.N. The Hidden Harvest: Wild Foods and Agricultural Systems. A Literature Review and Annotated Bibliography; International Institute for Environment and Development: London, UK, 1992.

10. Food Balance Sheets: A Handbook. Available online: ftp://ftp.fao.org/docrep/fao/011/x9892e/ x9892e00.pdf (accessed on 30 October 2013).

11. Bharucha, Z.; Pretty, J. The roles and values of wild foods in agricultural systems. Phil. Trans. Biol. Sci. 2010, 365, 2913-2926.

12. Modi, M.; Modi, A.T.; Hendriks, S. Potential Role for Wild Vegetables in Household food Security: A Preliminary Case Study in Kwazulu-Natal, South Africa. AJFAND 2006, 6, 1-13.

13. Etkin, N.L. Eating on the Wild Side: The Pharacologic, Ecologic, and Social Implications of Using Noncultigens; Etkin, N.L., Ed.; The University of Arizona Press: Tuscon, AZ, USA, 1994.

14. Kuhnlein, H.V.; Erasmus, B.; Spigelski, D. Indigenous Peoples' Food Systems: the Many Dimensions of Culture, Diversity and Environment for Nutrition and Health; FAO: Rome, Italy, 2009. 
15. Compton, J.; Wiggins, S.; Keats, S. Impact of the Global Food Crisis on the Poor: What Is the Evidence? UKAID: London, UK, 2010.

16. Institute of Development Studies. Accounts of Crisis: Poor People's Experiences of the Food, Fuel and Financial Crises in Five Countries; Hossain, N., Ebyen, R., Eds.; Institute of Development Studies: London, UK, 2009.

17. Corbett, J. Famine and Household Coping Strategies. World Dev. 1988, 16, 1099-1112.

18. Pilgrim, S.; Cullen, L.; Smith, D. Hidden Harvest or Hidden Revenue? Local resource use in a remote region of Southeast Sulawesi, Indonesia. IJTK 2007, 6, 150-159.

19. Gbetnkom, D. Forest Depletion and Food Security of Poor Rural Populations in Africa: Evidence from Cameroon. J. Afr. Econ. 2008, 18, 261-286.

20. Hadjichambis, A.C.; Paraskeva-Hadjichambi, D.; Della, A.; Elena Giusti, M.; de Pasquale, C.; Lenzarini, C.; Censorii, E.; Gonzales-Tejero, M.R.; Sanchez-Rojas, C.P.; Ramiro-Gutierrez, J.M.; et al. Wild and semi-domesticated food plant consumption in seven circum-Mediterranean areas. Int. J. Food Sci. Nutr. 2008, 59, 383-414.

21. Crush, J.S.; Frayne, G.B. Urban food insecurity and the new international food security agenda. Dev. South. Af. 2011, 28, 527-544.

22. Moseley, W.G.; Carney, J.; Becker, L. Neoliberal policy, rural livelihoods, and urban food security in West Africa: A comparative study of The Gambia, Cote d'Ivoire, and Mali. Proc. Natl. Acad. Sci. USA 2010, 107, 5774-5779.

23. Riley, L.; Legwegoh, A. Comparative urban food geographies in Blantyre and Gaborone. Afr. Geogr. Rev. 2013, doi: 10.1080/19376812.2013.805148.

24. De Schutter, O. Report submitted by the Special Rapporteur on the right to food. Available online: http://www2.ohchr.org/english/issues/food/docs/A-HRC-16-49.pdf (accessed on 30 October 2013).

25. De Schutter, O. Report of the Special Rapporteur on the right to food: Mission to Cameroon. Available online: http://www.ohchr.org/Documents/HRBodies/HRCouncil/RegularSession/ Session22/A-HRC-22-50-Add2_en.pdf (accessed on 30 October 2013).

26. FAO. Rome Declaration on World Food Security; In Proceedings of World Food Summit; Rome, Italy; 13-17 November 1996; FAO: Rome, Italy.

27. Brundtland, H. Our Common Future: Report of the World Commission on Environment and Development; United Nations: New York, NY, USA, 1987.

28. No more chicken, please: How a strong grassroots movement in Cameroon is successfully resisting damaging chicken imports from Europe, which are ruining small farmers all over West Africa. Available online: http://aprodev.eu/files/Trade/071203_chicken_e_final.pdf (accessed on 30 October 2013).

29. Comprehensive Food Security and Vulnerability Analysis: Guidelines. Available online: http://home.wfp.org/stellent/groups/public/documents/manual_guide_proced/wfp203202.pdf (accessed on 4 November 2013).

30. Carolan, M.S. The Wild Side of Agro-food Studies: On Co-experimentation, Politics, Change, and Hope. Sociol. Rural. 2013, 53, 413-431.

31. Tsing, A.L. Friction: An Ethnography of Global Connection; Princeton University Press: Princeton, NJ, USA, 2005. 
32. Kliskey, A.D.; Kearsley, G.W. Mapping multiple perceptions of wilderness in southern New Zealand. Appl. Geogr. 1993, 13, 203-223.

33. Thoreau, H.D. Walden, Or, Life in the Woods; Dover Publications: Mineola, NY, USA, 1995.

34. Stankey, G.H.; Schreyer, R. Attitudes toward Wilderness and Factors Affecting Visitor Behavior: A State-of-Knowledge Review. In Proceedings of National Wilderness Research Conference: Issues, State-of-Knowledge, Future Directions, Fort Collins, CO, USA, 23-26 July 1985; Intermountain Research Station: Ogden, UT, USA, 1985; pp. 246-293.

35. Neumann, R.P. Imposing Wilderness: Struggles Over Livelihood and Nature Preservation in Africa; University of California Press: Berkley, CA, USA, 1998.

36. Ndenecho, E.N. Ethnobotanic Resources of Tropical Mountane Forests: Indigenous Uses of Plants in the Cameroon Highland Ecoregion; Langaa Research and Publishing Cameroon Initiative Group: Bamenda, Cameroon, 2011.

37. Voeks, R.A. Are women reservoirs of traditional plant knowledge? Gender, ethnobotany and globalization in northeast Brazil. Singapore J. Trop. Geogr. 2007, 28, 7-20.

38. Harris, D.R.; Hillman, G.C. Foraging and Farming: The Evolution of Plant Exploitation; Unwin Hymen: London, UK, 1989.

39. Logan, M.H.; Dixon, A.R. Agriculture and the Acquisition of Medicinal Plant Knowledge. In Eating on the Wild Side: The Pharacologic, Ecologic, and Social Implications of Using Noncultigens; Etkin, N., Ed.; The University of Arizona Press: Tuscon, AZ, USA, 1994; pp. $24-45$.

40. Miller, N.F. The Origins of Plant Cultivation in the Near East. In The Origins of Agriculture: An International Perspective; Smithsonian Institution Press: Washington, DC, USA, 1992; pp. 39-58.

41. Cunningham, A.B. Applied Ethnobotany: People, Wild Plant. Use and Conservation; Earthscan: London, UK, 2001.

42. Vansina, J. Paths in the Rainforests: Toward a History of Political Tradition in Equatorial Africa; University of Wisconsin Press: Madison, WI, USA, 1990.

43. Posey, D.A.; Balick, M. Human impacts on Amazonia: the role of Traditional Ecological Knowledge in Conservation and Development; Columbia University Press: New York, NY, USA, 2006.

44. Posey, D.A. Indigenous management of tropical forest ecosystems: the case of the Kayapo indians of the Brazilian Amazon. Agrofor. Systems 1985, 3,139-158.

45. Johns, T.; Sthapit, B.R. Biocultural diversity in the sustainability of developing country food systems. Food Nutr. Bull. 2004, 25, 143-155.

46. Turner, N.J.; Łuczaj, Ł.J.; Migliorini, P.; Pieroni, A.; Dreon, A.L.; Sacchetti, L.E.; Paoletti, M.G. Edible and Tended Wild Plants, Traditional Ecological Knowledge and Agroecology. Crit. Rev. Plant. Sci. 2011, 30, 198-225.

47. Scott, J.C. The Moral Economy of the Peasant: Rebellion and Subsistence in Southeast. Asia; Yale University Press: New Haven, CT, USA, 1976.

48. Agrawal, A. Dismantling the Divide Between Indigenous and Scientific Knowledge. Dev. Change 1995, 26, 413-439.

49. IAASTD. Agriculture at A Crossroads International Assessment of Agricultural Knowledge, Science and Technology for Development; Island Press: Washington, DC, USA, 2009. 
50. Thrupp, L.A. Linking Agricultural Biodiversity and food security: The valuable role of agrobiodiversity for sustainable agriculture. Int. Aff. 2000, 76, 265-281.

51. Pieroni, A.; Nebel, S.; Santoro, R.F.; Heinrich, M. Food for two seasons: culinary uses of non-cultivated local vegetables and mushrooms in a south Italian village. Int. J. Food Sci. Nutr. 2005, 56, 245-272.

52. Frison, E.A.; Cherfas, J.; Hodgkin, T. Agricultural Biodiversity Is Essential for a Sustainable Improvement in Food and Nutrition Security. Sustainability 2011, 3, 238-253.

53. Doughty, J. Decreasing variety of plant foods used in developing countries. Qualitas Plant. 1979, 29, 163-177.

54. Turnbull, C.M. The Forest People: A study of the Pygmies of the Congo; Simon and Schuster: New York, NY, USA, 1962.

55. Sunderlin, W.D.; Angelsen, A.; Belcher, B.; Burgers, P.; Nasi, R.; Santoso, L.; Wunder, S. Livelihoods, forests, and conservation in developing countries: An Overview. World Dev. 2005, $33,1383-1402$.

56. Cerutti, P.O.; Tacconi, L. Forests, Illegality, and Livelihoods: The Case of Cameroon. Soc. Nat. Resour. 2008, 21, 845-853.

57. Aberoumand, A. Nutritional Evaluation of Edible Portulaca oleracia as Plant Food. Food Anal. Method. 2009, 2, 204-207.

58. Belcher, B.M. What isn't an NTFP? Int. Forest. Rev. 2003, 5, 161.

59. Shackelton, S.; Shanley, P.; Ndoye, O. Invisible but Vaible: recognizing local markets for non-timber forest products. Int. Forest. Rev. 2007, 9, 697-712.

60. Tieguhong, J.C.; Ndoye, O. The Impact of Timber Harvesting on the Availability of Non-Wood Forest Products in the Congo Basin; Food and Agriculture Organization: Rome, Italy, 2007.

61. Ndoye, O.; Perez, M.R.; Eyebe, A. The Markets of Non-timber Forest Products in the Humid Forest Zone of Cameroon; Overseas Development Institute: London, UK, 1997; pp. 1-25.

62. Ingram, V.; Ndoye, O.; Iponga, D.M.; Tieguhong, J.C.; Nasi, R. Les produits forestiers non ligneux: contribution aux economies nationales et strategies pour une gestion durable. Available online: http://dare.uva.nl/document/358169 (accessed on 30 October 2013).

63. Perez, M.R.; Ndoye, O.; Eyebe, A.; Puntodewo, A. Spatial characteristics of non-timber forest product markets in the humid forest zone of Cameroon. Int. Forest. Rev. 2000, 2, 71-83.

64. Nkem, J.; Kalame, F.B.; Idinoba, M.; Somorin, O.A.; Ndoye, O.; Awono, A. Shaping forest safety nets with markets: Adaptation to climate change under changing roles of tropical forests in Congo Basin. Environ. Sci. Pol. 2010, 13, 498-508.

65. Awono, A.; Ndoye, O.; Preece, L. Empowering Women's Capacity for Improved Livelihoods in Non-Timber Forest Product Trade in Cameroon. IJSF 2010, 3, 151-163.

66. Perez, M.R.; Ndoye, O.; Eyebe, A.; Ngono, D.L.; Pérez, M.R. A Gender Analysis of Forest Product Markets in Cameroon. Af. Today 2002, 49, 97-126.

67. Brown, K.; Lapuyade, S. A Livelihood from the Forest: Gendered Visions of Social, Economic and Environmental change in Southern Cameroon. J. Int. Dev. 2001, 13, 1131-1149.

68. Hughes, J. Just Famine Foods? What Contributions Can Underutilized Plants Make to Food Security? ISHS: Arusha, Tanzania, 2009; pp. 39-48.

69. Van Huis, A.; van Itterbeeck, J.; Klunder, H.; Mertens, E.; Halloran, A.; Muir, G.; Vantomme, P. Edible Insects: Future Prospects for Food and Feed Security; FAO: Rome, Italy, 2013. 
70. Vinceti, B.; Ickowitz, A.; Powell, B.; Kehlenbeck, K.; Termote, C.; Cogill, B.; Hunter, D. The Contribution of Forests to Sustainable Diets: Background paper for the International Conference on Forests for Food Security and Nutrition. Available online: http:/www.fao.org/forestry/37132051da8e87e54f379de4d7411aa3a3c32a.pdf (accessed on 30 October 2013).

71. Smith, I.F.; Longvah, T. Mainstreaming the Use of Nutrient-Rich Underutilized Plant Food Resources in Diets Can Positively Impact Family Food and Nutrition Security-Data from Northeast India and West Africa. In Proceedings of International Symposium on Underutilized Plants for Food Security, Nutrition, Income and Sustainable Development; Jaenicke, H., Ganry, J., Hoeschle-Zeledon, I., Kahane, R., Eds.; ISHS: Arusha, Tanzania, 2009; pp. 375-384.

72. Jones, M.P.; Sanyang, A. Underutilized Plants for Well-Being and Sustainable Development. In Proceedings of International Symposium on Underutilized Plants for Food Security, Nutrition, Income and Sustainable Development, March 3-6, 2008, Arusha, Tanzania; Jaenicke, H., Ganry, J.H.Z., Kahane, R., Eds.; ISHS: Arusha, Tanzania, 2009.

73. Tadele, Z. African Technology Development Forum Journal Special Issue: African Orphan Crops: Their Significance and Prospects for Improvement. Af. Technol. Dev. J. 2009, 6, 1-82.

74. Afari-Sefa, V.; Tenkouano, A.; Ojiewo, C.O.; Keatinge, J.D.H.; Hughes, J.A. Vegetable breeding in Africa: constraints, complexity and contributions toward achieving food and nutritional security. Food Secur. 2011, 4, 115-127.

75. Burchi, F.; Fanzo, J.; Frison, E. The Role of Food and Nutrition System Approaches in Tackling Hidden Hunger. Int. J. Environ. Res. Publ. Health. 2011, 8, 358-373.

76. Grivetti, E.L.; Ogle, B.M. Value of traditional foods in meeting macro- and micronutrient needs: The wild plant connection. Nutr. Res. Rev. 2000, 13, 31-46.

77. Johns, T. Plant Biodiversity and Malnutrition: Simple Solutions to Complex Problems. AJFAND 2003, 3, 45-52.

78. Cameroon: Comprehensive Food Security and Vulnerability Analysis. Available online: http://reliefweb.int/sites/reliefweb.int/files/resources/wfp250166.pdf (accessed on 4 November 2013).

79. Roger, D.D.; Justin, E.J.; Francois-xavier, E. Nutritional properties of "Bush Meals" from North Cameroon's Biodiversity. Adv. Appl. Sci. Res. 2012, 3, 1482-1493.

80. Maxwell, D. The Political Economy of Urban Food Security in Sub-Saharan Africa. World Dev. 1999, 27, 1939-1953.

81. Cohen, M.J.; Garrett, J.L. The food price crisis and urban food (in)security. Environ. Urban. 2010, 22, 467-482.

82. The State of Food Insecurity in the World; Food and Agriculture Organization of the United Nations: Rome, Italy, 2012.

83. United Nations World Urbanization Prospects: Cameroon; United Nations Department of Economic and Social Affairs: New York, NY, USA, 2011.

84. IMF. Cameroon: Poverty Reduction Strategy Paper IMF Country; Report No. 10/257; International Monetary Fund: Washington, DC, USA, 2010.

85. Toye, J. Development with dearer food: Can the invisible hand guide us? J. Int. Dev. 2009, 21, 757-764.

86. Appel, H.C. Walls and white elephants: Oil extraction, responsibility, and infrastructural violence in Equatorial Guinea. Ethnography 2012, 13, 439-465. 
87. Mason, N.M.; Jayne, T.S.; Chapoto, A.; Donovan, C. Putting the 2007/2008 global food crisis in longer-term perspective: Trends in staple food affordability in urban Zambia and Kenya. Food Pol. 2011, 36, 350-367.

88. Timmer, C.P. Reflections on food crises past. Food Pol. 2010, 35, 1-11.

89. Sneyd, L.Q.; Legwegoh, A.; Fraser, E.D.G. Food riots: Media perspectives on the causes of food protest in Africa. Food Secur. 2013, 5, 485-497.

90. Amin, J.A. Understanding the Protest of February 2008 in Cameroon. Af. Today 2012, 58, $20-43$.

91. Cooksey, B. Marketing Reform? The Rise and Fall of Agricultural Liberalisation in Tanzania. Dev. Pol. Rev. 2011, 29, S57-S81.

92. Swan, S.H.; Hadley, S.; Cichon, B. Crisis Behind Closed Doors: Global Food Crisis and Local Hunger. J. Agrarian Change 2010, 10, 107-118.

93. Dimova, R.; Gbakou, M. The Global Food Crisis: Disaster, Opportunity or Non-event? Household Level Evidence from Côte d'Ivoire. World Dev. 2013, 46, 185-196.

94. Popkin, B.M. The Nutrition Transition and its Health Implications in Lower-Income Countries. Publ. Health Nutr. 1998, 5, 205-214.

95. Popkin, B.M.; Gordon-Larsen, P. The nutrition transition: worldwide obesity dynamics and their determinants. Int. J. Obes. 2004, 28, S2-S9.

96. Blouin, C.; Hawkes, C.; Henson, S.; Drager, N.; Dube, L. Trade, Food, Diet. and Health: Perspectives and Policy Options; Wiley-Blackwell: Oxford, UK, 2010.

97. Lang, T. Crisis? What Crisis? The Normality of the Current Food Crisis. J. Agrarian Change 2010, 10, 87-97.

98. Mennen, L.I.; Mbanya, J.C.C.; Cade, J.; Balkau, B.; Sharma, S.; Chungong, S.; Cruickshank, J.K. The habitual diet in rural and urban Cameroon. Eur. J. Clin. Nutr. 2000, 54, 150-154.

99. Sharma, S.; Mbanya, J.C.; Cruickshank, K.; Cade, J.; Tanya, A.K.N.; Cao, X.; Hurbos, M.; Wong, M.R.K.M. Nutritional composition of commonly consumed composite dishes from the Central Province of Cameroon. Int. J. Food Sci. Nutr. 2007, 58, 475-485.

100. Satia, J.A. Dietary acculturation and the nutrition transition: an overview. Appl. Physiol. Nutr. Metabol. 2010, 35, 219-223.

101. United Nations Environment Programme. Republic of Cameroon: Biodiversity Status Strategy and Action Plan; Convention on Biological Diversity: Yaounde, Cameroon, 1999.

102. The Forests of the Congo Basin: State of the Forest 2006. Available online: http://carpe.umd.edu/ Documents/2006/THE_FORESTS_OF_THE_CONGO_BASIN_State_of_the_Forest_2006.pdf (accessed on 30 October 2013).

103. Guyer, J.I. The Food Economy and French Colonial Rule in Central Cameroun. J. Afr. Hist. 1978, 19, 577-597.

104. Ngoumou, T. Urban Food Provisioning in Cameroon: Regional Banana Plantain Network Linking Yaounde and the Villages of Koumou and Oban. In Economic Action in Theory and Practice: Anthropological Investigations; Wood, D.C., Ed.; Emerald: Bingley, UK, 2010; pp. 187-207.

105. Analyse Globale de la Sécurité Alimentaire et de la Vulnérabilité au Cameroun 2011. Available online: http://documents.wfp.org/stellent/groups/public/documents/ena/wfp250164.pdf (accessed on 4 November 2013), in French. 
106. Dogan, Y. Traditionally used wild edible greens in the Aegean Region of Turkey. Acta Soc. Bot. Pol. 2012, 81, 329.

107. Somnasanc, P.; Kaell, K.; Moreno-black, G. Knowing, Gathering and Eating: knowledge and attitudes about wild food in an Isan village in Northeastern Thailand. J. Ethnobiol. 2000, 20, 197-216.

108. Ogle, B.M.; Grivetti, E.L. Legacy of the cameleon edible wild plants of the Kingdom of Swaziland, South Africa. A Cultural, ecological and nutritional study. Part I. Introduction, objectives, methods, culture, landscape and diet. Ecol. Food Nutr. 1985, 16, 193-208.

109. Edwards, S.; Nebel, S.; Heinrich, M. Questionnaire surveys: methodological and epistemological problems for field-based ethnopharmacologists. J. Ethnopharmacol. 2005, 100, 30-36.

110. Miller, J.; Deutsch, J. Food Studies: An Introduction to Research Methods; Berg: Oxford, UK, 2009.

111. Legwegoh, A.F.; Hovorka, A.J. Assessing food insecurity in Botswana: the case of Gaborone. Dev. Pract. 2013, 23, 346-358.

112. Robben, A.C.G.M.; Sluka, J.A. Ethnographic Fieldwork: An Anthropological Reader; Blackwell Publishing: Oxford, UK, 2007.

113. Scheyvens, R.; Storey, D. Development Fieldwork: A Practical Guide; Sage: London, UK, 2008.

114. Baxter, J.; Eyles, J. Evaluating Qualitative Research in Social Geography: Establishing "Rigour" in Interview Analysis. Trans. Inst. Br. Geogr. 1997, 22, 505-525.

115. Clark, G. Onions are my Husband: Survival and Accumulation by West African Market Women; University of Chicago Press: Chicago, IL, USA, 1994.

116. Flynn, K.C. Food, Culture and Survival in an African City; Palgrave MacMillan: Basingstoke, UK, 2005.

117. Sultana, F. Reflexivity, Positionality and Participatory Ethics: Negotiating Fieldwork Dilemmas in International Research. Available online: http://www.acme-journal.org/vol6/FS.pdf (accessed on 30 October 2013).

118. Hayes-Conroy, A. Feeling Slow Food: Visceral fieldwork and empathetic research relations in the alternative food movement. Geoforum 2010, 41, 734-742.

119. Verpoorten, M.; Arora, A.; Stoop, N.; Swinnen, J. Self-reported food insecurity in Africa during the food price crisis. Food Pol. 2013, 39, 51-63.

120. Maxwell, D.; Caldwell, R. The Coping Strategies Index: Fields Methods Manual. Available online: http:/home.wfp.org/stellent/groups/public/documents/manual_guide_proced/wfp211058.pdf (accessed on 4 November 2013).

121. Koppert, G.J.A.; Dounias, E.; Froment, A.; Pasquet, P. Food Consumption in three forest populations of the Southern coastal area of Cameroon: Yassa, Mvae, Bakola. In Tropical Forests, People and Food: Biocultural interactions and applications to development; Hladik, C.M., Hladik, A., Linares, O.F., Pagezy, H., Semple, A., Hadley, S., Eds.; The Parthenon Publishing Group: Paris, France, 1993; pp. 295-310.

122. Yengoh, G.; Tchuinte, A.; Armah, F.; Odoi, J. Impact of prolonged rainy seasons on food crop production in Cameroon. Mitig. Adap. Strateg. Glob. Chang. 2010, 15, 825-841.

123. McCann, J. Stirring the Pot: A History of African Cuisine; Ohio University Press: Athens, Greece, 2009. 
124. Ancho-Chi, C. The Mobile Street Food Service Practice in the Urban Economy of Kumba, Cameroon. Singapore J. Trop. Geogr. 2002, 23, 131-148.

125. Mbaku, J.M. Culture and Customs of Cameroon; Greenwood Press: London, UK, 2005.

126. Tchoundjeu, Z.; Asaah, E.K.; Anegbeh, P.; Degrande, A.; Mbile, P.; Facheux, C.; Tsobeng, A.; Atangana, A.R.; Ngo-Mpeck, M.L.; Simons, A.J. Putting Participatory Domestication into Practice in West and Central Africa. For. Trees Livelihoods 2006, 16, 53-69.

127. Ngenge, T.S. The Institutional Roots of the "Anglophone Problem" in Cameroon. In Cameroon: Politics and Society in Critical Perspectives; University Press of America: Lanham, Maryland, 2003; pp. 61-86.

128. Takougang, J.; Krieger, M. African State and Soceity in the 1990s: Cameroon's Political Crossroads; Westview Press: Boulder, Colorado, CO, USA, 1998.

129. Konings, P. Crisis and Neoliberal Reforms in AFRICA: Civil Society and Agro-Industry in Anglophone Cameroon's Plantation Economy; Langaa RPCIG: Bamenda, Cameroon, 2011.

130. Maxwell, S.; Smith, M. Household Food Security: A Concpetual Review. In Household Food Security: Concepts, Indicators, Measurements: A Technical Review; UNICEF: New York, NY, USA, 1993.

131. Isichei, E. A History of African Societies to 1870; Cambridge University Press: Cambridge, UK, 1997.

132. Sneyd, A. Cameroon: Let them eat local rice. Available online: http:/www.africaportal.org/ articles/2012/08/27/cameroon-let-them-eat-local-rice (accessed on 30 October 2013).

133. Gockowski, J.; Mbazo'o, J.; Mbah, G.; Moulende, T.F. African traditional leafy vegetables and the urban and peri-urban poor. Food Pol. 2003, 28, 221-235.

134. Abia, W.A.; Numfor, F.A.; Wanji, S.; Tcheuntue, F. Energy and nutrient contents of "waterfufu and eru". Available online: http://akobatglobalmedia.typepad.com/files/energy-and-nutrientcontents-of-waterfufu-and-eru.pdf (accessed on 4 November 2013).

135. Ali, F.; Assanta, M.A.; Robert, C. Gnetum africanum: A Wild Food Plant from the African Forest with Many Nutritional and Medicinal Propertied. J. Med. Food 2011, 14, 1289-1297.

136. Kamga, R.; Kouame, C.; Akyeampong, E. Vegetable consumption patterns in Yaoundé, Cameroon. Afr. J. Food Nutr. Sci. 2013, 13, 7399-7414.

137. Gotor, E.; Irungu, C. The impact of Bioversity International's African Leafy Vegetables programme in Kenya. Impact Assess. Proj. Apprais. 2010, 28, 41-55.

138. Smith, F.; Eyzaguirre, P. African Leafy Vegetables: Their Role in the World Health Organization's Global Fruit and Vegetables Initiative. Available online: http://www.bioline.org.br/request?nd07019 (accessed on 4 November 2013).

(C) 2013 by the authors; licensee MDPI, Basel, Switzerland. This article is an open access article distributed under the terms and conditions of the Creative Commons Attribution license (http://creativecommons.org/licenses/by/3.0/). 